\title{
ГЕОХИМИЯ РАННЕГО ДИАГЕНЕЗА БОЛОТНЫХ ОТЛОЖЕНИЙ НА ПРИМЕРЕ ГОЛОЦЕНОВОГО РАЗРЕЗА ТОРФЯНИКА ДУЛИХА (Восточное Прибайкалье)
}

Леонова Г. А., Мальцев А. Е., Бобров В. А., Меленевский В. Н., Бычинский В. А., Мирошниченко Л. В.

\begin{abstract}
Аннотация
Детально исследованы два керна болотных отложения торфяника Дулиха мощностью 4.0 и 5.2 м. Выявлен восстановительный тип диагенеза. Установлено, что распад органического вещества болотных отложений начинается уже в верхних интервалах разреза на самых ранних стадиях диагенеза. Микробиологические исследования выявили в торфянике высокую численность органотрофных, аммонифицирующих, нитрифицирующих, фосфатмобилизирующих микроорганизмов, присутствие $\mathrm{Fe}-\mathrm{Ox}, \mathrm{Mn}-\mathrm{Ox}$ микроорганизмов и почти полное отсутствие сульфатредуцирующих бактерий (за исключением нижних интервалов торфяного разреза). Процессы круговорота азота, фосфора, а также углерода, проходят более активно, чем серы. Установлено изменение химического состава болотных вод в процессе диагенеза. Выявлен рост концентраций HCO3-, NH4+, PO43-, NO3- и Сорг по разрезу торфяника, что является следствием деструкции органического вещества, в результате которой в болотные воды переходят наиболее подвижные и лабильные компоненты. Результаты физико-химического моделирования показывают, что высокое содержание органического вещества приводит к существенному изменению химического состава болотных вод. Обогащение болотных вод $\mathrm{Cu}, \mathrm{Zn}, \mathrm{Sr}, \mathrm{Ba}, \mathrm{As}, \mathrm{Si}, \mathrm{Al}$ и $\mathrm{Pb}$ указывает на диагенетическое преобразование материала болотных отложений. Смена окислительных условий на восстановительные в толще торфяной залежи приводит к восстановлению окисленных формы Fe (III), Mn (IV) до подвижных форм Fe (II), Mn (II) и их дальнейшей миграции в болотную воду из твердой фазы отложений. С глубиной в торфе начинают доминировать восстановленные формы S (II), что указывает на рост восстановительных условий среды. Выявлено падение концентраций SO42- в воде минеральных отложений, подстилающих торф, что маркирует начало процесса сульфатредукции. Однако в болотных отложениях данный процесс идет очень вяло вследствие кислых условий среды и меньшей степени преобразованности органического вещества.
\end{abstract}

\section{Ключевые слова:}

Верховое болото, диагенез, болотные воды, геохимические индикаторы диагенеза, аутигенное минералообразование, органическое вещество, торф 


\title{
ГЕОХИМИЯ РАННЕГО ДИАГЕНЕЗА БОЛОТНЫХ ОТЛОЖЕНИЙ НА ПРИМЕРЕ ГОЛОЦЕНОВОГО РАЗРЕЗА ТОРФЯНИКА ДУЛИХА
} (Восточное Прибайкалье)

\author{
Г.А. Леонова ${ }^{1}$, А.Е. Мальцев ${ }^{1}$, В.А. Бобров ${ }^{1}$, В.Н. Меленевский ${ }^{2}$, \\ В.А. Бычинский ${ }^{3}$, Л.В. Мирошниченко ${ }^{1}$ \\ ${ }^{1}$ Институт геологии и минералогии им. В.С. Соболева СО РАН, \\ 630090, Новосибирск, проспект Академика Коптюга, 3 \\ ${ }^{2}$ Институт нефтегазовой геологии и геофизики им. А.А. Трофимука СО РАН, \\ 630090, Новосибирск, проспект Академика Коптюга, 3 \\ ${ }^{3}$ Институт геохимии им. А.П. Виноградова СО РАН, \\ 664033, Иркутск, ул. Фаворского, 1 А
}

Детально исследованы два керна болотных отложения торфяника Дулиха мощностью 4.0 и 5.2 м. Выявлен восстановительный тип диагенеза. Установлено, что распад органического вещества болотных отложений начинается уже в верхних интервалах разреза на самых ранних стадиях диагенеза. Микробиологические исследования выявили в торфянике высокую численность органотрофных, аммонифицирующих, нитрифицирующих, фосфатмобилизирующих микроорганизмов, присутствие Fe-Ox, MnОх микроорганизмов и почти полное отсутствие сульфатредуцирующих бактерий (за исключением нижних интервалов торфяного разреза). Процессы круговорота азота, фосфора, а также углерода, проходят более активно, чем серы. Установлено изменение химического состава болотных вод в процессе диагенеза. Выявлен рост концентраций $\mathrm{HCO}_{3}{ }^{-}, \mathrm{NH}_{4}{ }^{+}, \mathrm{PO}_{4}{ }^{3-}, \mathrm{NO}_{3}{ }^{-}$и $\mathrm{C}_{\text {орг }}$ по разрезу торфяника, что является следствием деструкции органического вещества, в результате которой в болотные воды переходят наиболее подвижные и лабильные компоненты. Результаты физико-химического моделирования показывают, что высокое содержание органического вещества приводит к существенному изменению химического состава болотных вод. Обогащение болотных вод $\mathrm{Cu}, \mathrm{Zn}, \mathrm{Sr}, \mathrm{Ba}$, $\mathrm{As}, \mathrm{Si}, \mathrm{Al}$ и $\mathrm{Pb}$ указывает на диагенетическое преобразование материала болотных отложений. Смена окислительных условий на восстановительные в толще торфяной залежи приводит к восстановлению окисленных формы Fe (III), Mn (IV) до подвижных форм Fe (II), Mn (II) и их дальнейшей миграции в болотную воду из твердой фазы отложений. С глубиной в торфе начинают доминировать восстановленные формы S (II), что указывает на рост восстановительных условий среды. Выявлено падение концентраций $\mathrm{SO}_{4}{ }^{2-}$ в воде минеральных отложений, подстилающих торф, что маркирует начало процесса сульфатредукции. Однако в болотных отложениях данный процесс идет очень вяло вследствие кислых условий среды и меньшей степени преобразованности органического вещества.

Верховое болото, диагенез, болотные воды, геохимические индикаторы диагенеза, аутигенное минералообразование, органическое вещество, торф

\section{ВВЕДЕНИЕ}


Строение торфяной залежи отражает временные аспекты многих процессов на протяжении длительного временного интервала (голоцена). Биогеохимическая миграция химических элементов позволяет рассматривать особенности их распределения за всю историю формирования болотного массива [Ефремова и др., 2003]. Распределение химических элементов по глубине торфяной залежи является важной характеристикой процессов формирования, эволюции и деградации болот [Савичев и др., 2019]. Значительный интерес представляют исследования аккумуляции химических элементов в болотах и механизмы аутигенного минералообразования. Хотя изучение торфяных залежей весьма актуально как в практическом, так и теоретическом аспектах, данные о геохимии торфяников Сибири по полным голоценовым разрезам весьма ограничены. Они касаются, прежде всего, определения общего содержания битуминозных компонентов торфа [Архипов и др., 2008], изучения веществ гуминовой природы [Савельева и др., 2010], геохимии болотных вод [Шварцев и др., 2012], а также геохимии отдельных химических элементов [Савичев, Шмаков, 2012; Веретенникова, 2013; Савичев и др., 2019 и др.]. Вместе с тем, комплексных исследований геохимии раннего диагенеза болотных отложений Восточной Сибири не проводилось, вследствие чего, протекающие по глубине разрезов торфяных залежей биогеохимические процессы остаются изучены недостаточно полно.

Раннедиагенетические изменения болотных отложений контролируются окислительно-восстановительными процессами, которые проявляются, в первую очередь: 1) в перераспределении химических элементов по глубине разреза торфяника; 2) в изменении и превращении форм нахождения химических элементов минеральной части торфов; 3) в изменении (трансформации) состава болотных вод. Все перечисленные изменения минеральной составляющей в разрезах торфяников происходят за счет энергии процессов бактериального разложения органического вещества. Деструкция органического вещества в поверхностном кислородонасыщенном слое торфа протекает с образованием $\mathrm{CO}_{2}$, преимущественно в аэробных условиях. В толще торфяной залежи, где кислорода нет, процессы минерализации органического вещества протекают в анаэробных условиях, важнейшими из которых являются: метанообразование, денитрификация, разложение аминокислот, восстановление марганца, железа и др.

На восточном побережье оз. Байкал широко развиты природные болотные комплексы (евтрофные, мезотрофные и олиготрофные), расположенные на типичных конечноморенных валах, каких много в устьях троговых долин, спускающихся к Байкалу с окружающих хребтов [Ляхова, Косович, 1990; Намсараев и др., 2009]. Олиготрофные торфяники, расположенные на междуречьях, являются наиболее перспективными для исследования процессов диагенеза болотных отложений юго-восточного побережья оз. Байкал, в том числе и болотный массив Дулиха. Нашими предшественниками [Безрукова и др., 2000; Krivonogov, Takahara, 2003; Krivonogov et al., 2004] получена детальная летопись позднеплейстоценовой и голоценовой истории юго-восточного побережья оз. Байкал по результатам палинологического анализа и определения ботанического состава болотных отложений скважины Дулиха. Однако, детальные биогеохимические исследования диагенеза болотных отложений Восточного Прибайкалья не проводились.

С учетом этого, в течение более десяти лет авторами проводятся комплексные геохимические исследования болот Прибайкалья. Нами исследован разрез монолита (50 cм) торфяника Дулиха по распределению в нем химических элементов, естественных 
$\left({ }^{210} \mathrm{~Pb},{ }^{226} \mathrm{Ra},{ }^{232} \mathrm{Th},{ }^{238} \mathrm{U},{ }^{40} \mathrm{~K}\right)$ и техногенных $\left({ }^{137} \mathrm{Cs},{ }^{241} \mathrm{Am}\right)$ радиоизотопов [Бобров и др., 2019]. Также были проведены геохимические исследования по распределению ряда химических элементов в разрезах торфяника Дулиха (4.0 и 5.2 м) и болотных водах [Леонова и др., 2017; Мальцев и др., 2019]. Однако, глубокого обобщения полученных данных, которые бы позволили представить полную картину геохимии раннего диагенеза торфяных отложений, нами не было достигнуто, что и стало целью данной работы.

Для решения поставленной цели в ходе исследования нами решались следующие задачи:

1) детально изучить строение полных разрезов торфяных залежей, что позволит судить об условиях торфообразования за весь исторический период голоцена;

2) исследовать распределение по глубине разрезов микроэлементов, биогенных элементов (C, H, N, S), показателей отношения $\mathrm{C}_{\text {орг }} / \mathrm{N}_{\text {орг }}$ и физиологических групп микроорганизмов, что даст представление о различии вещественного состава стратифицированных слоев торфяников, деструкции органического вещества в раннем диагенезе и механизмах аутигенного минералообразования;

3) установить изменение химического состава болотных вод по глубине разреза торфяника, что позволит выявить механизмы перераспределения химических элементов между твердой и жидкой фазами торфяников.

Таким образом, исследование геохимии раннего диагенеза по полным голоценовым разрезам болота Дулиха позволит внести существенный вклад в понимание процессов континентального диагенеза органогенных отложений.

\section{ОБЪЕКТ И МЕТОДЫ ИССЛЕДОВАНИЯ}

Болото Дулиха расположено на Танхойской равнине, на юго-восточном побережье Байкала. Равнина ограничена береговой линией озера с севера и хребтом Хамар-Дабан с юга. Равнина представляет собой часть дна Байкальской впадины, тектоническое движение которой связано с поднятием хребта Хамар-Дабан [Иметхенов, 1987; Мац и др., 2001; Mats, 1992]. В основном равнина сложена слабо дислоцированными палеогеновыми и неогеновыми отложениями, объединенными в танхойскую свиту. Четвертичные отложения распространены в меньшей степени. Более определенно распознаются геологические образования позднего плейстоцена. Отложения этого возраста представлены конечными моренами первого позднеплейстоценового оледенения, расположенными на равнине напротив крупных троговых долин хребта Хамар-Дабан. В голоцене на Танхойской равнине преобладали следующие процессы седиментации: заболачивание междуречных пространств, речная деятельность и формирование низких террас озера Байкал [Безрукова и др., 2000, 2005; Krivonogov, 2009]. Согласно [Krivonogov et al., 2004] время начала торфонакопления болота Дулиха оценивается в 11.2 т.л.н.

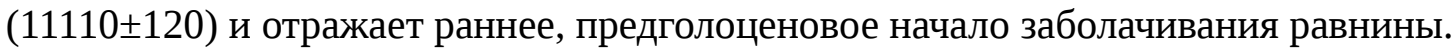

В 2011 г. бурение торфяника Дулиха было проведено совместно с Институтом геохимии СО РАН тонкостенным поршневым пробоотборником с помощью бурильной установки, состоящей из вышки с грузоподъемными механизмами и бура с набором штанг.

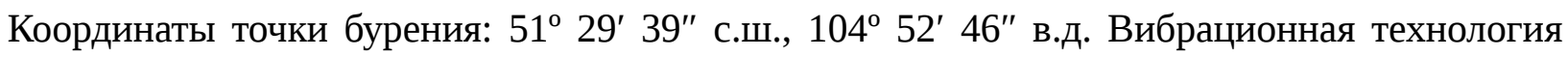
бурения позволила вскрыть всю толщу торфяной залежи до подстилающих пород и получить 2 непрерывных керна торфа диаметром 7.5 см и длиной 4.0 м (рис. 1a). В 2018 году было проведено дополнительное бурение болота Дулиха в той же точке торфяным буром БТГ-1 и получен керн мощностью 5.2 м (рис. 1б). В кернах бурения сразу же после 
их разгрузки из пробоотборника измеряли неустойчивые параметры - значения $\mathrm{pH}$ и Eh. Затем керны были упакованы в полиэтилен и пластиковые пеналы и в ненарушенном состоянии доставлены в Институт геологии и минералогии СО РАН. В лабораторных условиях керны были разрезаны на фрагменты через 10 см и 50 см для различных видов анализов.

Строение разрезов торфяника Дулиха представлено на рис. 1. Мощность торфяной залежи составляет от 390 см (керн 2011 года бурения) до 500 см (керн 2018 года бурения). Ниже залегают органо-минеральные отложения мощностью 10-20 см, которые подстилают лёссовидные суглинки. Самые верхние интервалы (0-10 см) представлены почти неразложившимся торфом с большим количеством растительных остатков (осок) и сфагнового мха. Верхний интервал торфяников (10-124 см и 10-200 см соответственно) представлен слаборазложившимся торфом (степень разложения менее 20 \%) с большим количеством сфагнового мха. В керне 2011 года в верхнем интервале установлен небольшой прослой торфа (50-79 см), в котором содержание осок преобладает над сфагновым мхом (рис. 1a). Ниже залегает интервал более темного разложившегося торфа разной мощности: от 100 см (керн 2018 г.) до 172 см (керн 2011 г.). Самые нижние интервалы представлены сильноразложившимся торфом (степень разложения более 50 \%) темно-шоколадного цвета мощностью от 71 см (2011 г.) до 180 см (2018 г.).

Авторами данной работы ботанический состав торфа не проводился. В работах Е.В. Безруковой с соавторами [2000, 2005] приводится ботанический состав торфяника Дулиха по данным спорово-пыльцового анализа. Торфяная залежь болота Дулиха на всём протяжении представлена остатками эвтрофных и мезотрофных растений: мхи, папоротникообразные, плаунообразные, голосеменные и покрытосеменные. Представители рода Carex (осоки) доминируют в торфе: среднее содержание остатков осок по всем горизонтам залежи составляет 40-50 \%. Во всех торфяных слоях значительно содержание Schzeuchzeria palustris L. (шейцерия), которое составляет в среднем 20-30 \% [Безрукова и др., 2000, 2005]. В работе [Безрукова и др., 2000] отмечается слабое изменение болотного биоценоза в течение всего времени накопления торфа, то есть, отсутствие значительных изменений локальной растительности. Согласно [Безрукова и др., 2000], вскрытый торфяник, за исключением его нижних горизонтов, относится к торфам переходного типа, нижний слой торфа относится к низинному типу.

Зольность основного интервала торфяника Дулиха (0-310 см) для керна 2011 года бурения (мощностью 400 см) составляет 5.2-9.6 \%, с дальнейшим увеличением вниз по разрезу (310-380 см) до 11.1-15.4\% (рис. 1a). Самый нижний интервал торфа (380390 см) характеризуется резким ростом зольности до $27.7 \%$. Зольность основного интервала разреза (0-350 см) для керна 2018 года бурения (мощностью 520 см) торфяника Дулиха невелика и составляет 3.6-5.0 \%, с дальнейшим незначительным увеличением вниз по разрезу (350-500 см) до 5.4-5.6\% (рис. 1б). Можно выделить резкий рост зольности в нижнем интервале торфа 400-450 см до 26.8 \%, а также незначительный рост зольности в самых верхних 30 см торфа до $6.4 \%$.

Болотную воду из верхних 50 см керна 2 торфяника на гидрохимический анализ отбирали на месте в пластиковые 1.5-литровые бутылки и не консервировали. Сразу после отбора в пробах воды проводили измерение $\mathrm{pH}$ и окислительно-восстановительного потенциала (Eh). Воду на микроэлементы отбирали в полиэтиленовые контейнеры и консервировали добавлением концентрированной азотной кислоты (особо чистая) из расчета 4 мл кислоты на 1 л раствора [Руководство.., 1983]. Болотную воду из разреза 
керна получали в лабораторных условиях из 50-сантиметровых фрагментов торфа путем отжима в пресс-форме диаметром 6 см с помощью гидравлического пресса в герметичные пробирки, чтобы ограничить доступ кислорода.

Гидрохимический анализ (определение $\mathrm{HCO}_{3}{ }^{-}, \mathrm{CO}_{3}{ }^{2-}, \mathrm{Cl}^{-}, \mathrm{SO}_{4}{ }^{2-}, \mathrm{NO}_{3}{ }^{-}, \mathrm{NO}_{2}{ }^{-}, \mathrm{PO}_{4}{ }^{3-}$, $\mathrm{NH}_{4}^{+}$), растворенный $\mathrm{O}_{2}$, БПК общепринятых методик [Методика..., 2004; Методика..., 2005; Массовая..., 2006] в Лаборатории контроля качества природных и сточных вод Федерального государственного учреждения «ВерхнеОбьрегионводхоз». Методом атомно-эмиссионной спектроскопии с индуктивно связанной плазмой (ИСП-АЭС) в болотных водах и образцах торфа определены концентрации $\mathrm{Si}, \mathrm{Al}, \mathrm{B}, \mathrm{Ba}, \mathrm{Ca}, \mathrm{Mg}, \mathrm{Sr}, \mathrm{P}, \mathrm{Na}, \mathrm{K}, \mathrm{Li}, \mathrm{Cr}, \mathrm{Ni}, \mathrm{Co}, \mathrm{Mo}, \mathrm{Fe}, \mathrm{Mn}, \mathrm{Cu}$, $\mathrm{Zn}, \mathrm{As}, \mathrm{Sb}$, Ti. Анализы проведены в Центре коллективного пользования научным оборудованием для многоэлементных и изотопных исследований Института геологии и минералогии СО РАН (ЦКП МИИ СО РАН).

Для расчета форм нахождения химических элементов в болотных водах применен программный комплекс «Селектор-С». Расчет форм нахождения был проведен в Институте геохимии СО РАН согласно методике [Карпов, 1981; Чудненко, 2010]. Алгоритм программного комплекса «Селектор-С» основан на методе минимизации свободной энергии Гиббса гетерогенной системы. Теоретические основы физикохимического моделирования включают в себя условия равновесия в гетерогенных многокомпонентных системах с ограничениями в виде линейных уравнений баланса масс.

В ЦКП МИИ СО РАН методом атомно-абсорбционной спектрометрии (ААС) в торфе определены концентрации $\mathrm{Fe}, \mathrm{Al}, \mathrm{Ca}, \mathrm{Mg}, \mathrm{K}, \mathrm{Na}, \mathrm{Mn}, \mathrm{Ba}, \mathrm{Sr}, \mathrm{Zn}, \mathrm{Co}, \mathrm{Ni}, \mathrm{Cu}, \mathrm{Pb}, \mathrm{Cr}, \mathrm{V}, \mathrm{Li}$, $\mathrm{Cd}, \mathrm{Sb}, \mathrm{Be}$. При определении $\mathrm{Hg}$ применена методика «холодного пара» с амальгамацией на золотом сорбенте. Элементный анализ органического вещества (C, H, N, S) в образцах торфа выполнен по методике [Фадеева и др., 2008] на автоматическом CHNS-анализаторе в Институте органической химии СО РАН. Формы серы (общая, сульфатная и сульфидная) в образцах торфа были определены по стандартной методике [Определение..., 2015] в Институте катализа СО РАН. Для определения зольности торфа проведено озоление образцов при $\mathrm{t}=+450^{\circ} \mathrm{C}$ в муфельной печи.

Микробиологические исследования (определение численности и послойное распределение по разрезам торфяника основных физиологических групп микроорганизмов) проведены в Лимнологическом институте СО РАН. Использована стандартная методика и ее модифицированные версии посева проб суспензий торфа из кернов и подсчет колоний аэробных и анаэробных бактерий [Намсараев, Земская, 2000].

Пиролитический метод в варианте Рок-Эвал (RE-пиролиз) применен для исследования трансформации органического вещества торфа на ранних этапах диагенеза в ненарушенных кернах торфяника. Пиролиз проводили в Институте нефтегазовой геологии и геофизики CO РАН на анализаторе SR Analyzer, Humble Instruments согласно подходу [Тиссо, Вельте, 1981; Меленевский и др., 2011]. Суть метода заключается в программируемом нагреве анализируемого образца в контролируемой атмосфере. На первом этапе нагрев осуществляется в атмосфере гелия с последующим определением выделившихся углеводородов (УВ), на втором этапе остаток образца (после первого нагрева) окисляется в атмосфере кислорода с определением $\mathrm{CO}_{2}$ и расчетом общего количества органического углерода (ТОС), водородного (НI) и кислородного (ОI) индексов. Водородный индекс (HI - hydrogen index) является отношением количества органических соединений $S_{2}$ на содержание органического углерода (ТOC) в образце (мг 
УВ/кг ТОС). Кислородный индекс (OI — oxygen index) показывает количество $\mathrm{CO}_{2}$ (пик $\mathrm{S}_{3}$ ) относительно органического углерода (мг $\left.\mathrm{CO}_{2} / \Gamma \mathrm{TOC}\right)$.

Методом рентгеновской порошковой дифрактометрии исследован минеральный состав образцов торфа в разрезах торфяников на дифрактометре ДРОН-4, излучение $\mathrm{Cu}-$ К $\alpha$ в ЦКП МИИ СО РАН. Рентгенофлуоресцентным анализом по общепринятой методике [Унифицированные.., 1979] определены основные породообразующие оксиды в образцах торфа, а методом рентгеноспектрального электронно-зондового микроанализа (РСМА) проведено исследование образцов торфа в Институте геохимии СО РАН.

Сканирующую электронную микроскопию (СЭМ) применяли для изучения микроморфологии и вещественного состава образцов торфа с использованием сканирующего электронного микроскопа TESCAN MIRA 3 LMU в ЦКП МИИ CO РАН. Применяли различные режимы детектирования: режим вторичных электронов, позволяющий получить данные о морфологии рельефа; режим отраженных электронов или режим фазового контраста, который дает возможность получить картину распределения электронной плотности в исследуемой пробе; режим характеристического рентгеновского излучения, позволяющий провести рентгеноспектральный микроанализ и получить данные по элементному составу образца [Goldstein, 1981].

\section{ГЕОХИМИЯ ОРГАНИЧЕСКОГО ВЕЩЕСТВА}

Распределение основных биогенных элементов. Согласно [Gentsch et al., 2015] содержание азота, углерода и серы в торфе отражает изменение органического вещества (ОВ) при торфообразовании. На рис. 2 представлено распределение по разрезу торфяника Дулиха основных биогенных элементов: $(\mathrm{C}, \mathrm{H}, \mathrm{N})_{\text {орг }}$ и S, P. Самые верхние 10 см торфа характеризуются более низкими содержаниями $(\mathrm{C}, \mathrm{H}, \mathrm{N})_{\text {орг }}$, что, как мы считаем [Бобров и др., 2019], связано с разубоживанием торфа терригенным материалом, который активно поступает на поверхность торфяника с атмосферными выпадениями (пыль). Эти же интервалы характеризуются резким ростом валовых значений S (0.16\%) и особенно $\mathrm{P}$ (0.15 \%), что может быть также следствием увеличения доли терригенной компоненты в материале торфа, которое подтверждается незначительным ростом зольности (рис. 2). Ниже по разрезу торфяника (50-150 см) отмечается резкое увеличение содержаний $\mathrm{C}_{\text {орг }} \mathrm{C}$ 44.25 до 54.12 \%, с дальнейшим трендом на уменьшение содержаний с глубиной (150350 см) до 36.01-49.43\%. Такое снижение значений $\mathrm{C}_{\text {орг }}$ может быть следствием деструкции ОВ торфа в диагенезе согласно [Геохимия диагенеза..., 1980].

Кривая $\mathrm{H}$ и $\mathrm{N}$ вниз по разрезу торфяника имеет менее выдержанный характер распределения, чем распределение $\mathrm{C}_{\text {орг }}$ - это связано, по-видимому, с тем, что данные элементы «лучше» маркируют смену ботанического состава торфяника. К нижним интервалам торфа (350-385 см) отмечается тренд на резкое снижение концентраций всех биогенных элементов (C, H, N) орг. Эти интервалы характеризуются очень сильным разложением материала торфа. В отличие от $\mathrm{C}, \mathrm{H}$ и $\mathrm{N}$, распределение $\mathrm{P}$ и $\mathrm{S}$ по разрезу торфяника имеет довольно выдержанные значения на уровне 0.07-0.09 \% и 0.14-0.16 \% соответственно, с заметным ростом в нижних (310-390 см) высокозольных интервалах торфа, которые характеризуются резким ростом содержаний S с 0.20 до 0.36-0.39 \% и Р с 0.09 до 0.15-0.21\% (рис. 2). Органоминеральные отложения (385-400 см) характеризуются резким падением содержаний всех элементов: С до 16.71, H - 2.12, N $0.90, \mathrm{~S}-0.26, \mathrm{P}-0.08 \%$. 
Генезис органического вещества. Распределение отношения $\mathrm{C} / \mathrm{N}$ по разрезам озерно-болотных отложений является широко используемым органо-геохимическим маркером источников поступления и генезиса современного и захороненного органического вещества [Ветров и др., 2008; Меленевский и др., 2011; Беляев, 2015; Леонова и др., 2019]. Отношение $\mathrm{C} / \mathrm{N}$ косвенно (из-за неопределенности степени диагенетической трансформации ОВ) подтверждает генетическую связь ОВ отложений с исходным органическим материалом либо автохтонным - планктон и макрофиты $(\mathrm{C} / \mathrm{N}=$ 6-7), либо аллохтонным - наземная и полупогруженная растительность ( $\mathrm{C} / \mathrm{N}=12-40)$ [Ветров и др., 2008]. Установлено, что отношение $\mathrm{C} / \mathrm{N}$ в торфянике Дулиха изменяется по разрезу от 17.9 до 25.1 (рис. 2), а средние значения C/N составляют 19.9. Это указывает на то, что в разрезе торфяника Дулиха присутствует в большом количестве ОВ аллохтонного происхождения, представленное преимущественно высшей наземной растительностью (осоки, сфагновые мхи). Полученные нами значения отношения $\mathrm{C} / \mathrm{N}$ в разрезе торфяника Дулиха сходны со значениями $\mathrm{C} / \mathrm{N}$ осоково-сфагнового типа торфяников Западной Сибири (C/N = 21.0-21.6) согласно [Архипов, Маслов, 1998].

Характер распределения кривой отношения $\mathrm{C} / \mathrm{N}$ имеет некое подобие «синусоиды» - в ней четко выделяются максимумы и минимумы. Так, максимальные значения отношения $\mathrm{C} / \mathrm{N}$ отмечаются в интервалах 80-90 см $(\mathrm{C} / \mathrm{N}=22.6), 240-250$ см $(\mathrm{C} / \mathrm{N}=25.1)$ и 380-390 см (C/N = 21.4\%), а минимальные значения $\mathrm{C} / \mathrm{N}$ характерны для интервалов 2030 см $(\mathrm{C} / \mathrm{N}=15.0), 150-160$ см $(\mathrm{C} / \mathrm{N}=17.5)$ и 310-320 см $(\mathrm{C} / \mathrm{N}=17.8 \%)$. Минимальные значения отношения $\mathrm{C} / \mathrm{N}$ могут свидетельствовать о присутствии в материале торфа древесно-травяной растительности [Архипов, Маслов, 1998].

Основные закономерности превращения органического вещества в диагенезе. Измерение значений окислительно-восстановительного потенциала Eh показали, что диагенетические процессы преобразования органического вещества в болотном массиве Дулиха происходят в анаэробных условиях. Только самые верхние интервалы отложений характеризуются окислительными условиями среды. На рис. 3 показан расчет общего количества органического углерода (ТОС), водородного (НI) и кислородного (ОI) индексов. Значения НI и ОI определяют качество (тип) ОВ. Вызывает интерес тренд изменения НI, TOC, ОI от глубины: практически при постоянстве ТОС и ОI происходит почти четырехкратное уменьшение НI, т.е. окисление ОВ торфа. Поскольку в раннем диагенезе изменение химического состава ОВ в соответствии с общепринятым мнением [Tissot, Welte, 1978; Конторович, 1976] возможно за счет бактериальной деятельности и изменения состава первичных продуцентов, то в качестве наиболее вероятной причины установленного факта можно остановиться на втором факторе. Постоянство в распределении НI характерно для интервала 400-300 cм, а резкое уменьшение НI наблюдается в интервале 0-300 см, что, по-видимому, маркирует смену низинного типа торфа переходным типом торфа.

Несмотря на разный состав первичных продуцентов, органическое вещество торфа в равной степени подвергается деструкции в диагенезе. По данным пиролиза установлено, что уже в самых верхних интервалах болотных отложений органическое вещество подвержено глубоким процессам трансформации и существенно отличается по составу от одного из продуцентов ОВ - сфагнового мха (рис. 4). Анализируя формы пирограмм (хроматографические спектры продуктов пиролиза), было установлено, что они являются суперпозицией трех пиков максимального выхода углеводородов ( $\left.\mathrm{T}_{\text {пик}}\right)$ : низкотемпературный пик с $\quad \mathrm{T}_{\text {пик }}<300^{\circ} \mathrm{C}$, промежуточный, представленный 
углеводородами, образовавшимися за счет разложения лабильного компонента OB, с $\mathrm{T}_{\text {пик }} \approx$ 300-400 ${ }^{\circ} \mathrm{C}$ и высокотемпературный пик с $\mathrm{T}_{\text {пик }} \approx 400-500{ }^{\circ} \mathrm{C}$, характерный для зрелого ОВ (керогена). Наличие в пирограммах двух последних пиков указывает на присутствие в материале торфа углеводородных продуктов пиролиза - керогена и смолистоасфальтеновых веществ $\left(300-650^{\circ} \mathrm{C}\right.$, мг УВ/г породы). Сравнительный анализ форм пирограмм по разрезу торфяника показывает, что в их составе отсутствуют лабильные белково-углеводные вещества, представленные низкотемпературными пиками, за исключением слаборазложившегося торфа из интервала 0-5 см (рис. 4). Присутствие данного пика в верхнем интервале торфа свидетельствует о меньшей степени преобразованности ОВ торфа в сравнении с нижележащими горизонтами. Однако, распад попадающего в болотные отложения ОВ начинается уже в верхних интервалах торфа на самых ранних стадиях диагенеза.

Характер пирограмм торфа в сравнении с исследованными нами озерными сапропелями Сибири [Меленевский и др., 2011; Леонова и др., 2018, 2019; Leonova et al., 2019] показывает меньшую преобразованность ОВ в диагенезе. В отличие от пирограмм сапропелей, таковые торфа не имеют четко выраженных высокотемпературных пиков, «зачатков» макромолекулярной структуры керогена - это высокотемпературная ( $\mathrm{T}_{\text {пик }}>$ $400{ }^{\circ} \mathrm{C}$ ) часть пирограмм, соответствующая углеводородам, находящимся в биополимере в химически связанном состоянии с высокой энергией связи. Отсутствие выраженных высокотемпературных пиков свидетельствует, во-первых, об ином источнике поставке ОВ, во-вторых, о меньшей степени деструкции захороненного органического вещества торфяника. По-видимому, «жесткая» наземная растительность, формирующая торф, состоящая преимущественно из трудногидролизуемых веществ, в частности содержащая большое количество лигнина и целлюлозы [Потехин и др., 2010], требует большего времени для фоссилизации.

\section{РАСПРЕДЕЛЕНИЕ МИКРООРГАНИЗМОВ И ИХ РОЛЬ В ПРОЦЕССАХ ДИАГЕНЕЗА}

Распределение различных физиологических групп микроорганизмов по разрезу болотных отложений представлено в табл. 1. Самая высокая численность органотрофных микроорганизмов (OM), использующих в качестве источников энергии и углерода широкий спектр органических соединений, отмечена в средних (250-260 см) и нижних (450-460 см) интервалах болотных отложений и в подстилающих торф глинах. В торфе самая высокая численность аммонифицирующие микроорганизмов (АМБ) установлена в самых верхних интервалах керна (0-10 cм). Присутствие в торфе группы нитрифицирующих бактерий (НБ) наблюдается только в верхних интервалах торфа (030 см), ниже по разрезу данная группа микроорганизмов не обнаружена. Отмечается рост численности денитрифицирующих бактерий (ДНБ) вниз по разрезу торфяника. Самая высокая численность данной группы микроорганизмов установлена в интервале 350520 см. Максимальная численность фосфатмобилизирующих (ФМБ) микроорганизмов была установлена в верхней части торфяной залежи (0-110 см). Ниже по разрезу численность ФМБ резко падает, примерно на порядок. Присутствие сульфатредуцирующих бактерий (СРБ), напротив, отмечается только в самых нижних интервалах (450-520 см) торфяника Дулиха. Выше по разрезу торфа СРБ нами не обнаружены. 
В ходе исследований установлено активное участие микроорганизмов в трансформации ОВ в процессе раннего диагенеза, где под их воздействием происходит деструкция лабильных компонентов органического вещества. В этом процессе одним из ключевых аспектов является круговорот углерода, с которым тесно сопряжены циклы азота, серы, фосфора и других химических элементов. Установлено, что при трансформации захороненного ОВ важная роль принадлежит микроорганизмам, принимающим участие в цикле азота, таким как аммонифицирующие (АМБ), нитрифицирующие (НБ) и денитрифицирующие бактерии (ДНБ). Высокая численность АМБ и НБ в верхних интервалах торфа свидетельствует о присутствии азотсодержащих органических веществ, способных вовлекаться в процессы аммонификации. Согласно [Савичев и др., 2019] падение численности НБ с глубиной является следствием ухудшения аэробных условий в торфяной залежи. Рост численности ДНБ вниз по разрезу торфяника свидетельствует о том, что ведущую роль в круговороте азота в глубоких горизонтах торфа в анаэробных условиях начинает играть данная группа микроорганизмов, которая для завершения процессов деградации ОВ использует продукты аммонификации и нитрификации - результат жизнедеятельности АМБ и НБ при деструкции азотсодержащих органических соединений верхних интервалов торфа.

Фосфатмобилизирующие (ФМБ) микроорганизмы способны переводить минеральные соединения фосфора в растворимые формы, доступные другим организмам, в виде фосфат-анионов. Установлено, что характер распределения ФМБ по глубине разреза зависит от окислительно-восстановительных условий среды. В нижних интервалах торфяника с Eh $<0$ затруднено микробное окисление фосфатов, поэтому численность ФМБ резко снижается по глубине разреза с $21-248 \mathrm{KOE} / \Gamma \times 10^{3}$ (0-110 см) до 0.7-5.5 KOЕ/Г×103 (250-520 см) (табл. 1).

Наиболее информативными для понимания процессов диагенетического преобразования минерального вещества торфа является послойное распределение численности железоокисляющие (Fe-OX) и марганецокисляющие бактерий (Mn-OX), участвующих в процессах окислении $\mathrm{Fe}^{2+}$ до $\mathrm{Fe}^{3+}$ и $\mathrm{Mn}^{2+}$ до $\mathrm{Mn}^{4+}$ из растворенных соединений при участии кислорода, а также сульфатредуцирующих бактерий (СРБ), участвующих в процессах восстановления $\mathrm{SO}_{4}{ }^{2-}$ до $\mathrm{H}_{2} \mathrm{~S}$ с использованием лабильных компонентов органического вещества. Согласно [Гранина, 2008], основные факторы, влияющие на численность и распределение Fe-OX и Mn-OX бактерий, это окислительновосстановительные условия среды, содержание органического вещества в отложениях, наличие растворенных форм $\mathrm{Fe}$ и $\mathrm{Mn}$ в болотных водах. Железоокисляющие и марганецокисляющие микроорганизмы активно развиваются только в верхних (0-30 см), интервалах торфяника, где их численность составляет до 13600 и $6500 \mathrm{KOE} / г$ осадка соответственно (табл. 1). Эти интервалы характеризуются окислительными условиями среды $(\mathrm{Eh}=+245 \mathrm{MB})$, высокими содержаниями органического вещества $\left(\mathrm{C}_{\text {орг }}=44.3 \%\right.$, POУ = 140 мг/л), наличием растворенных форм Fe (5.2) и Mn (0.06 мг/л). Мы предполагаем, что Fe-OX и Mn-OX микроорганизмы играют ведущую роль в процессах окисления восстановленных форм железа и марганца в раннем диагенезе болотных отложений, что также подтверждается рядом работ [Лукашев и др., 1971; Гранина, 2008; Юдович, Кетрис, 2014].

В распределении сульфатредуцирующих бактерий наблюдается противоположная картина - присутствие их только в самых нижних интервалах разреза, в подстилающих торфяник органо-минеральных и минеральных отложениях (табл. 1). Мы предполагаем, 
что наличие сульфатредуцирующих бактерий именно в этих интервалах торфяника может свидетельствовать о максимальной степени деструкции ОВ, так как СРБ способны использовать только низкомолекулярное органическое вещество (прежде всего ацетат, лактат, летучие жирные кислоты и пируват), прошедшее предварительную деградацию сложных органических молекул, катализируемую другими группами микроорганизмов [Trudinger et al., 1972; Геохимия диагенеза..., 1980; Иванов, Каравайко, 2004; Юдович, Кетрис, 2011]. Это означает, что присутствие в болотных отложениях большого количества слабо разложившегося органического вещества в анаэробных условиях не благоприятствует развитию СРБ, которые требуют более глубокой предварительной деструкции ОВ. Именно в органо-минеральных отложениях меньшее содержание ОВ (Сорг $=16.7 \%$ и и более длительное время захоронения способствуют максимально эффективной его «переработке» органотрофными микроорганизмами до низкомолекулярных компонентов. Кислые условия среды (pH = 3.2-4.4) в торфяных отложениях также не способствуют развитию СРБ. Так, например, оптимальный интервал значений $\mathrm{pH}$ для развития рода Desulfovibrio составляет 6.3-8.6 (в общих случаях СРБ развиваются в средах с рН равным 4-10) согласно [Волков, 1984]. Рост значений $\mathrm{pH}$ до 5.6-6.7 в органоминеральных и минеральных отложениях может благоприятно сказываться на развитие сульфатредуцирующих микроорганизмов.

Таким образом, можно заключить, что в исследованном торфянике болотного массива Дулиха процессы круговорота азота, фосфора, а также углерода, проходят более активно, чем серы. Биогеохимические процессы цикла углерода охватывают всю толщу торфяной залежи. Однако, так как интенсивность и направленность данного процесса в разных горизонтах торфа согласно [Сергеева, Инишева, 2008] определяется генезисом захороненного органического вещества и длительностью торфообразования - нижние горизонты торфа, с наиболее преобразованным ОВ, характеризуются максимальной активностью органотрофных микроорганизмов. Самые верхние интервалы торфа являются благоприятной средой для микробного окисления восстановленных форм Fe и Mn. Высокая численность разных физиологических групп микроорганизмов в самых нижних интервалах торфяника Дулиха свидетельствует о жизнеспособном состоянии микробного комплекса на глубине.

\section{ГЕОХИМИЯ МИНЕРАЛЬНОЙ ЧАСТИ ТОРФЯНИКА}

Минеральный состав болотных отложений. Главные породообразующие минералы зольной части торфа - это слюда, кварц, плагиоклаз, бассанит, КПШ; второстепенными являются хлорит, акцессорными - амфибол, иллит (рис. 5). В верхних интервалах (0-10 cм) обнаружен гематит. Пирит был обнаружен только в органоминеральных отложениях и глинах, подстилающих торфяник, в интервалах 390-400 и 520 см. Результаты исследования методом рентгеноспектрального электронно-зондового микроанализа (РСМА) показали, что в минеральном составе торфа присутствуют также альбит и карбиды. Практически во всех образцах встречаются единичные мелкие, яркие частицы огранённой и полуогранённой формы с высоким содержанием Fe, Ti, Ca, Ba и W. Минеральная составляющая этих частиц, возможно, представлена магнетитами, титанитами, единичными металлическими гранулами. В образцах поверхностного интервала торфяника (0-20 см) наблюдаются частицы сферической формы, элементный состав которых выражен такими элементами, как: C, O, Al, Si, Ca, Fe, P, S с различным процентным соотношением содержаний. Возможно, это могут быть алюмосиликатные 
спёки, связанные с пожарами (на что может указывать присутствие гематита), или какието вторичные минеральные образования, связанные с воздействием техногенных источников. Гематиту свойственна сезонная цикличность и связь с пожарами на ожелезненных торфяниках [Лукашев и др., 1971]. Так, согласно [Fischer, Schwertmann, 1975] гематит образуется в результате «внутренней дегидратации» агрегированного аморфного гидроксида Fe (III) (предположительно, ферригидрита) в обводненных условиях при $\mathrm{pH}$ 6-7 и температуре от $70^{\circ} \mathrm{C}$ (оптимальная температура образования в лабораторных условиях - 240 $\mathrm{C}$ ) в присутствии оксалата (иногда без него). Поэтому, вполне вероятно, образование данного минерала вследствие пожаров на торфянике Дулиха.

Сканирующая электронная микроскопия (СЭМ) показала, что верхние интервалы торфяника (0-50 см) болота Дулиха содержат в своем составе большое количество аутигенных частиц оксида железа в виде корок и псевдоморфоз по растительным остаткам, размерностью от 2 до 80 мкм (рис. 6а, б). Помимо этого, в этих же интервалах нами были обнаружены наночастицы сульфидов железа с примесью Sb размером около 5 мкм. Мы предполагаем, что они также могут иметь аутигенную природу. В более глубоких горизонтах торфа установлено присутствие самородного Fe (рис. 6в). Новообразованные наночастицы самородного Fe являются агрегатами хлопьевидных частиц, имеющих неплотную структуру размером до 15 мкм. Аморфная форма микрочастиц Fе и их ассоциация с растительными остатками торфа свидетельствует в пользу их аутигенного происхождения согласно [Рождествина, Сорокин, 2010]. В глубоких горизонтах торфяников, имеющих низкие значения водородного показателя (pH), окислительно-восстановительного потенциала (Eh), подвижно большинство металлов, в том числе и Fе. В таких условиях (на фоне отсутствия активной сульфатредукции) вполне возможно формирование самородных форм железа.

Присутствие пирита по данным СЭМ в материале торфа не установлено, однако в нижних горизонтах торфяника (520 см) в большом количестве по растительным остаткам мхов обнаружены псевдоморфозы Fе следующего состава: S (до 3-5 вес. \%) и О (до 15 вес. \%), (рис. 6г). Мы предполагаем, что псевдоморфозы Fe вполне могут быть гидротроилитом $\left(\mathrm{FeS} \times \mathrm{nH}_{2} \mathrm{O}\right)$. Можно предположить, что процесс формирования минералов железа в торфянике Дулиха близок к начальным стадиям диагенеза, а аутигенные оксиды, гидроксиды и сульфиды железа являются членами одного минералогического ряда, в пределах которого они связаны между собой через изменение окислительно-восстановительных условий среды (Eh), значений $\mathrm{pH}$ в болотных водах и деятельности сульфатредуцирующих бактерий. $\mathrm{O}$ незавершенности процессов минералообразования в торфянике свидетельствуют такие факты, как гелеобразное агрегатное состояние минеральных масс, псевдоморфозы, отсутствие четко выраженной структуры кристаллов.

Формы серы. Данные по формам серы в болотных отложениях торфяника Дулиха представлены на рис. 7. В верхних, менее восстановленных интервалах торфяных отложений, преобладающей формой серы является S (IV) - сера в составе сульфатов. Однако, даже в самых верхних интервалах торфа установлено присутствие небольшого количества восстановленных форм S (II), т.е. серы в составе сульфидов Fe, $\mathrm{H}_{2} \mathrm{~S}$ и др. C глубиной начинают доминировать восстановленные формы S (II). Таким образом, в торфянике Дулиха наблюдается рост восстановительных условий среды вниз по разрезу болотных отложений. В то же время аутигенные, сульфидные минералы в твердой фазе 
торфяника не выявлены. Возможно, обнаруженная S (II) - это сера в составе сероводорода и органического вещества. Согласно [Лукашев и др., 1971] в торфах сера сульфатов, восстанавливаясь, связывается в структурах органического вещества в форме сульфидных групп (SH), поэтому, даже на фоне довольно высоких (1-6 мг/л) содержаний в болотных водах растворенного железа образование аутигенных сульфидов $\mathrm{Fe}$ не происходит. Помимо этого, большая часть растворенного железа в составе болотных вод образует комплексные соединения с органическим веществом [Шварцев и др., 2012]. Повидимому, это может делать его недоступным для дальнейшего включения в процессы бактериальной сульфатредукции. В таких условиях в болотных экосистемах согласно [Labrenz et al., 2000] возможно образование сульфидов цинка (ZnS, сфалерит), что было установлено нами [Бобров и др., 2011] в разрезе верхового Выдринского болота (Южное Прибайкалье), расположенного в 14 км от торфяника Дулиха.

Распределение химических элементов. Распределение ряда химических элементов по глубине разреза торфяника Дулиха представлено на рис. 8. По характеру распределения кривых выделяется группа элементов, характеризующаяся хорошо выраженными максимумами содержаний в самых верхних интервалах торфяника: $\mathrm{Fe}, \mathrm{Mn}, \mathrm{Cu}, \mathrm{Pb}, \mathrm{Zn}, \mathrm{Cd}$, As, Hg. Характер распределения Fe по профилю торфяной залежи определяется окислительно-восстановительными условиями среды. Увеличение содержаний Fe в верхних слоях торфа может быть отражением процессов формирования его оксидов и гидроксидов, вследствие окисления восстановленных (растворенных) форм Fe (II), поступающих из нижележащих горизонтов, и выпадение их в твердую фазу осадка. Высокие значения в верхних интервалах торфа для ряда халькофильных элементов (Pb, $\mathrm{Zn}, \mathrm{Cd}, \mathrm{Hg}, \mathrm{As})$ связаны с антропогенной нагрузкой на экосистему болота Дулиха в XXXXI вв. Эти элементы входят в группу воздушных мигрантов (так называемых «летучих»), характеризующих загрязненность современной атмосферы согласно [Гавшин, 2003; Ходжер, 2005], и могут быть напрямую связаны с атмосферным аэрозолем, отражая время его поступления на земную поверхность. Стоит отметить довольно резкий рост содержаний As в интервале 50-70 см, что может быть следствием изменения ботанического состава торфа - преобладанием в его составе осок (Carex) и снижение сфагнового мха. Согласно [Василевич, 2017] осоки отличаются наибольшей избирательностью биогенного накопления As. Для $\mathrm{Pb}$ и $\mathrm{Zn}$ также характерно резкое увеличение их содержаний в высокозольных слоях торфа (380-390 см) и в подстилающих их органоминеральных отложениях (390-400 см), что обусловлено резким ростом минеральной компоненты, в частности алюмосиликатного материала. Высокие содержания $\mathrm{Cu}$ и $\mathrm{Mn}$ в верхнем слое торфяника связаны с их биофильным характером накопления [Бобров и др., 2019] при образовании зеленой массы сфагнового мха. Еще одним источником накопления Mn в верхнем слое торфа может быть, как и для железа, осаждение растворенных форм Mn (II) на окислительно-восстановительном барьере в виде оксидов и гидроксидов. Поэтому, биогеохимия $\mathrm{Mn}$ в ходе накопления торфа определяется главным образом спецификой биогенной аккумуляции растенийторфообразователей и окислительным геохимическим барьером. На границе смены типа торфа различного ботанического состава (80-85 см) отмечается резкое увеличение содержаний Mn с 94 до 241 мг/кг.

Отдельно выделяются литофильные элементы группы алюминия (Al, K, Na, Si), для которых характерна корреляция с распределением зольности по разрезам. Для этой группы элементов не выявлено значительного увеличения в верхних интервалах торфа (рис. 8). 
Для них характерно резкое увеличение содержаний в самых нижних высокозольных интервалах торфа и в подстилающих торф органоминеральных отложениях. Поскольку Al и $\mathrm{Si}$ являются одними из основных зольных компонентов торфов, то соответственно, с увеличением зольности в исследованном разрезе торфяника синхронно увеличиваются и содержания Al и Si. Данные элементы поступают в материал торфа в составе кварца и тонкодисперсных глинистых минералов (слюда, плагиоклаз, КПШ, хлорит), которые содержат в своем составе также K, Na. Это определяет сходство в распределении $\mathrm{Al}, \mathrm{K}$, $\mathrm{Na}, \mathrm{Si}$ по разрезу торфяника. Отдельно следует выделить группу щелочноземельных элементов $\mathrm{Ca}, \mathrm{Mg}$ и $\mathrm{Sr}$, которые характеризуются относительно устойчивым увеличением содержаний по глубине разреза торфяника с максимальными значениями в верхних интервалах торфа (0-10 cм). Рост содержаний $\mathrm{Ca}, \mathrm{Mg}$ и $\mathrm{Sr}$ по разрезу торфяника может косвенно указывать на изменение водного режима и обводненности болота на этапах его развития в голоцене.

Для V характерны выдержанные содержания в интервале торфяника (0-220 см) на уровне 1-9 мг/кг и заметное увеличение его содержаний к нижним интервалам торфа (220-380 см) с 11 до 41 мг/кг, с дальнейшим резким увеличением в высокозольных слоях торфа и органоминеральных отложениях до 64-125 мг/кг. Довольно выдержанные значения V в интервале 0-220 см можно связать с малой подвижностью данного элемента в кислых водах гумидных ландшафтов согласно [Ефремова и др., 2003]. Увеличение содержание $\mathrm{V}$ по глубине разреза торфа, возможно, связано с ростом значений $\mathrm{pH}$ в сторону более щелочных условий среды (с 3.2 до 4.8 в торфе и 7.2 - в глине).

Стоит отметить заметное увеличение содержаний Ва и Ве в интервале 315-375 см (представленных сильно-разложившимся сфагновым торфом) от 107 до 247 и от 0.24 до 0.42 мг/кг соответственно. Также выявлено снижение содержаний Ва и Ве в интервале 265-275 см (представленных торфом с преобладанием осок до 50 \%) от 142 до 103 и от 0.18 до 0.07 мг/кг соответственно. Для Ве отмечен еще один существенный рост его содержаний до 1.9 мг/кг в интервале 200-250 см. По-видимому, такое распределение этих элементов по разрезу отражает изменение вещественного состава торфа, на что косвенного указывает и распределение $\mathrm{Br}$ - довольно выдержанное с более высокими содержаниями (на уровне 17-22 мг/кг) в интервале 210-380 см. Такое распределение $\mathrm{Br}$ может свидетельствовать о изменении солевого состава болотных вод по глубине разреза. По-видимому, на этапе формирования низинного торфяника происходил рост минерализации болотных вод и содержаний $\mathrm{Cl}^{-}$, что приводило к накоплению $\mathrm{Br}$ в торфе. Самый верхний, слаборазложившийся интервал торфа (0-10 см) и самый нижний, высокозольный (380-390 см) характеризуются минимальными содержаниями $\mathrm{Br}$ на уровне 8-9 мг/кг.

\section{ТРАНСФОРМАЦИЯ ХИМИЧЕСКОГО СОСТАВА БОЛОТНЫХ ВОД}

Основной ионный состав. Химический состав болотных вод из разных горизонтов торфяника Дулиха представлен в табл. 2 и на рис. 9. Болотные воды по преобладающим ионам относятся к типично глеевым, практически не содержащим в своем составе гидрокарбонат-ионов, по щелочно-кислотным условиям они относятся к классу кислых $(\mathrm{pH}=3.2-4.8)$, по величине общей минерализации (20-56 мг/л) - к семейству ультрапресных вод [Алекин, 1970; Перельман, 1982]. Наблюдается рост $\mathrm{HCO}_{3}{ }^{-}$с глубиной до 5.49-7.93 мг/л, при этом в верхних интервалах торфа присутствие данного аниона не установлено, что характерно для кислых болотных вод. По разрезу отмечены 
выдержанные концентрации $\mathrm{SO}_{4}{ }^{2-}$ на уровне 1.8-2.9 мг/л, которые только в самом нижнем интервале падают до 0.5 мг/л вследствие процессов бактериальной сульфатредукции. Установлен существенный рост содержаний $\mathrm{Cl}^{-}$в болотных водах с глубиной от 1.3 до 7.9 мг/л. Отмечен рост ионов $\mathrm{Ca}^{2+}$ и $\mathrm{Mg}^{2+}$ по разрезу от 5.1 до 12.6 и от 0.9 до 2.5 мг/л соответственно. Рост содержаний $\mathrm{Na}^{+}$и $\mathrm{K}^{+}$выражен менее заметно и составляет 2.5-3.9 и 0.78-0.89 мг/л соответственно. При этом в болотных водах отмечается преобладание ионов $\mathrm{Na}^{+}$над $\mathrm{Mg}^{2+}$. Выщелачивание минеральной составляющей торфяника приводит к увеличению в болотной воде нижних интервалов торфяника $\mathrm{Ca}^{2+}, \mathrm{Mg}^{2}, \mathrm{Cl}^{-}$и отчасти $\mathrm{Na}^{+} . \mathrm{B}$ распределении $\mathrm{PO}_{4}{ }^{3-}$, в целом, установлено увеличение содержаний с глубиной от 0.14 до 0.65 мг/л. В распределении $\mathrm{NO}_{3}{ }^{-}$и $\mathrm{NH}_{4}{ }^{+}$по разрезу отмечена тенденция к повышению концентраций с глубиной. Болотные воды торфяной залежи Дулиха содержат большое количество органических веществ (РОУ = 140-208 мг/л).

Трансформация химического состава болотных вод в диагенезе. Основным показателем изменения физико-химических свойств болотных отложений в диагенезе является снижение окислительно-восстановительного потенциала с глубиной (табл. 2), что определяет восстановительный тип диагенеза. Снижение показателя Eh до отрицательных значений является, в первую очередь, следствием деструкции ОВ и бактериальным потреблением кислорода. Диагенетические преобразования материала торфа приводят к существенной метаморфизации болотных вод с глубиной (рис. 9). Так, в составе болотных вод с глубиной увеличивается доля $\mathrm{HCO}_{3}{ }^{-}, \mathrm{Cl}^{-}, \mathrm{NO}_{3}^{-}, \mathrm{NH}_{4}^{+}$и $\mathrm{Ca}^{2+}$.

Отражением деструкции органического вещества в анаэробных условиях является увеличение содержания $\mathrm{HCO}_{3}^{-}$по глубине разреза - и, как следствие, метаморфизация болотных вод в диагенезе. Присутствие кислорода в верхних интервалах торфа и аэробная деструкция органического вещества повышает $\mathrm{P}_{\mathrm{CO} 2}-$ это смещает карбонатное равновесие в сторону образования $\mathrm{H}_{2} \mathrm{CO}_{3}$ и определяет полное отсутствие иона $\mathrm{HCO}_{3}{ }^{-}$в составе слабоминерализованных болотных вод. Данный процесс создает кислые условия среды. Смена окислительных условий на восстановительные (приводящее к снижению $\mathrm{P}_{\mathrm{Co2}}$ ) по глубине разреза на фоне роста $\mathrm{Ca}^{2+}$ смещает карбонатное равновесие в сторону образования $\mathrm{HCO}_{3}^{-}$, что определяет увеличение значений $\mathrm{pH}$ с глубиной. Минерализация микроорганизмами азотосодержащего органического вещества (образование $\mathrm{NH}_{3}$ ) также повышает $\mathrm{pH}$. Дальнейшая анаэробная деструкция органического вещества определяет рост содержаний $\mathrm{HCO}_{3}{ }^{-}$в болотных водах.

Минерализация органического вещества торфа в диагенезе приводит к росту концентраций $\mathrm{NH}_{4}{ }^{+}$и $\mathrm{NO}_{3}{ }^{-}$в болотных водах по глубине разреза. Этот процесс идет при непосредственном участии микроорганизмов. Одним из источников увеличения нитратиона в болотных водах верхних интервалов торфяной залежи может быть окисление аммиака при участии бактерий-нитрификаторов. Рост содержаний $\mathrm{NO}_{3}{ }^{-}$вниз по разрезу торфа возможно является как следствием колебания уровня болотных вод, так и отражением процессов анаэробного окисления аммония при участии микроорганизмов (например, анаммокс-бактерий). Несмотря на анаэробное окисление аммония, активная минерализация органического вещества в анаэробных условиях обеспечивает рост концентраций $\mathrm{NH}_{4}{ }^{+}$по глубине торфяника. Диссимиляторная нитрат-редукция до аммония может сохранять в болотных водах образующийся $\mathrm{NH}_{4}{ }^{+}$на высоком уровне, преобладая над процессом денитрификации в условиях повышенного содержания $\mathrm{C}_{\text {орг }}$.

Распределение ряда химических элементов (Al, Si, Fe, Mn, B, Sr, Ba, Hg, Pb, Cu, Zn, $\mathrm{V}, \mathrm{As})$ в болотных водах по глубине разреза торфяника Дулиха представлено на рис. 10. 
Характер распределения растворенных химических элементов по разрезу отражает происходящие процессы диагенетического преобразования торфа, приводящие к метаморфизации болотных вод. Эти процессы заключаются в выщелачивании ряда элементов в болотную воду из твердой фазы торфяника и/или повторное осаждение их из болотных вод. Для самого верхнего слоя торфа (0-10 см) отмечается рост в составе болотных вод содержаний $\mathrm{Fe}, \mathrm{Pb}, \mathrm{Hg}$., что является следствием растворения глинистых минералов, а также фильтрации болотных вод через массу оторфованных растений. В диагенезе при смене окислительно-восстановительных условий в процессе разложения органического вещества изменяются физико-химические свойства болотных вод, что влияет на распределение химических элементов, имеющих переменную валентность - в первую очередь Fe и $\mathrm{Mn}$. Таким образом, снижение значений Eh приводит к восстановлению окисленных форм Fe (III), Mn (IV) до подвижных Fe (II), Mn (II) и их дальнейшей миграции в болотную воду из твердой фазы торфяных отложений. Верхний интервал торфа (10-200 см) характеризуется накоплением растворенных $\mathrm{Mn}, \mathrm{Ba}, \mathrm{P}, \mathrm{Zn}, \mathrm{Cu}$. Такое увеличение этих элементов возможно как следствие деструкции органического вещества, так и выщелачивания элементов из минеральной составляющей торфа. Максимальные концентрации $\mathrm{Fe}, \mathrm{Mn}, \mathrm{Zn}$ и $\mathrm{Cu}$, установленные в верхних интервалах торфа, связаны с образованием комплексных соединений с органическим веществом гуминового типа, что определяет большую их вероятность накапливаться в болотных водах [Шварцев и др., 2012].

С глубиной в болотных водах отмечается закономерный рост содержаний $\mathrm{Al}, \mathrm{Si}$ и $\mathrm{As}$. Органическое вещество играет большую роль в разрушении структур алюмосиликатных минералов и выносе алюминия согласно [Helmer et al., 1990]. В условиях повышенной кислотности торфяных залежей $\mathrm{Al}$ становится подвижным и способен легко переходить в состав болотных вод из твердой фазы торфяников. При минерализации остатков растений и разрушении глинистых частиц на фоне роста значений $\mathrm{pH}$ (где Si становится подвижен) болотные воды глубоких интервалов торфяника обогащаются растворенным кремнием.

Смена ботанического состава и типа торфа оказывает влияние на распределение ряда растворенных химических элементов. Так, в интервале 200-300 см, представленного разложившимся торфом, отмечается рост концентраций $\mathrm{B}, \mathrm{K}$, частично $\mathrm{Mn}, \mathrm{Ca}, \mathrm{Mg}$ и $\mathrm{Sr}$. Высокозольный интервал торфа (400-450 cм) характеризуется ростом содержаний V (от 5.5 до 16 мкг/л), S (от 4.5 до7.6 мг/л) и резким падением $\mathrm{Pb}$ (от 9.9 до 1.5 мкг/л). В сильно разложившихся интервалах торфа (300-490 см) отмечается резкий рост концентраций As от 0.4 до 4.7 мкг/л. Отдельно выделяется самый нижний интервал торфа (450-500 см), для которого характерно значительное увеличение концентраций растворенных $\mathrm{Ca}, \mathrm{Mg}, \mathrm{Sr}$, $\mathrm{Mn}$, что может быть следствием растворения карбонатных минералов. Воды минеральных отложений, подстилающих торфяную залежь, характеризуются ростом концентраций элементов преимущественно терригенной компоненты - paстворенных $\mathrm{Al}, \mathrm{Si}, \mathrm{Na}, \mathrm{K}$ и $\mathrm{Ba}$.

Стоит отметить, что в торфяниках характер изменения химического состава болотных вод по вертикальному профилю связан (помимо дигенетических преобразований) с интенсивностью водообмена. Поэтому согласно [Савичев, 2015] на распределение растворенных химических элементов (особенно для верхних горизонтов) влияет характер колебаний уровня болотных вод, который в свою очередь, определяется современным состоянием болота, условиями увлажнения и дренированности. Положение уровня болотных вод и амплитуда их изменения определяется положением границы 
доступа кислорода и обусловливает смену фильтрационных свойств, т.е. размещение биогеохимических барьеров.

Формы нахождения химических элементов в болотных водах. Результаты физикохимического моделирования компонентного состава болотных вод с использованием программного комплекса «Селектор-С» [Карпов, 1981; Чудненко, 2010], показали (табл. 3), что Ba, Ca, K, Li, Mg, Mn, Na, Ni, Sr, Cd, Cо присутствуют в виде простых ионов. Hg, B, $\mathrm{Cu}, \mathrm{V}, \mathrm{Si}, \mathrm{Sb}, \mathrm{As}$ существуют в виде окислов и гидроокислов, $\mathrm{Pb}, \mathrm{Zn}$ в виде карбонатов. Результаты расчетов показали, что независимо от того, закрыта система или открыта по отношению к атмосфере, основными формами миграции Сa, $\mathrm{Na}, \mathrm{Mn}, \mathrm{Mg}, \mathrm{K}, \mathrm{Sr}, \mathrm{Ni}, \mathrm{Co}$, Cd, Ва, а также хлора, в болотных водах являются их простые катионные формы. Этим объясняется их равномерное распределение по исследованному профилю болотных отложений. Величины содержания остальных форм этих элементов на два, три, четыре порядка меньше. Для щелочноземельных элементов (Сa, Mg, Sr) следующими по значимости являются карбонатные формы. Для таких элементов как $\mathrm{Cu}, \mathrm{Zn}, \mathrm{Pb}$ преобладающей химической формой являются гидрокарбонаты. Кремний, хром, мышьяк присутствуют в виде окислов и гидроокислов, церий в виде соединения $\mathrm{CeNO}_{3}{ }^{2+}$. Основными формами содержания $\mathrm{S}$ и $\mathrm{Cl}$ являются их основные анионные формы $\mathrm{SO}_{4}{ }^{2-}$ и $\mathrm{Cl}^{-}$, однако часть серы также присутствует в форме растворенных соединений $\mathrm{CaSO}_{4}{ }^{0}$ и $\mathrm{MgSO}_{4}{ }^{0}$. Это показывает необходимость использования физико-химического моделирования для корректировки аналитических данных. Одной из главных форм углерода в составе болотных вод является $\mathrm{HCO}_{3}{ }^{-}$, содержание которого, не обнаруживает зависимости от степени взаимодействия с атмосферой. Следующим по содержанию углеродным соединением является растворенная углекислота. Верхние интервалы торфа (0-50 см) характеризуются более низкими содержаниями гидрокарбонатных форм для всех элементов, чем нижележащие интервалы. Содержания алюминия и железа в модельных водах существенно отличается от аналитических. Это связано с тем, что в болотных водах они существуют в метастабильном состоянии вследствие деструкции органического вещества. В модельных расчетах это окислы, тогда как в условиях болотных вод возможно существование их соединений со сложными органическими кислотами, в том числе с азот содержащими.

Результаты физико-химического моделирования позволяют сделать важный вывод высокое содержание органического вещества приводит к существенному изменению состава болотных вод. Количество растворенных форм алюминия и железа возрастает, поскольку исследованные отложения бескарбонатные, то преобладающими формами существования элементов в растворе являются простые ионы, окислы и гидроокислы, гидрокарбонаты имеют подчиненное значение.

\section{ВЫВОДЫ}

1. Распад органического вещества торфа начинается уже в верхних интервалах болотных отложений на самых ранних стадиях диагенеза. Характер форм пирограмм из разных интервалов торфяника показал, что в составе органического вещества отсутствуют лабильные белково-углеводные вещества, представленные низкотемпературными пиками, характерными для растений-торфообразователей (биопродуцентов). Но, в отличие от пирограмм озерных сапропелей, пирограммы торфа не имеют четко выраженных высокотемпературных пиков, «зачатков» макромолекулярной структуры керогена, что 
указывает на меньшую степень деструкции органического вещества торфяника в диагенезе.

2. Высокая численность органотрофных, аммонифицирующих, нитрифицирующих, фосфатмобилизирующих микроорганизмов на фоне почти полного отсутствия сульфатредуцирующих бактерий указывает на то, что в торфянике процессы круговорота $\mathrm{C}, \mathrm{N}$ и $\mathrm{P}$ проходят более активно, чем S. Присутствие в болотных отложениях большого количества слабо разложившегося органического вещества не благоприятствует развитию сульфатредукторов, которые требуют более глубокой предварительной деструкции органического вещества. Биогеохимические процессы охватывают всю толщу торфяной залежи, однако, максимальной интенсивности достигают к нижним наиболее преобразованным горизонтам торфа, на что указывает высокая численность органотрофных микроорганизмов. Самые верхние интервалы торфа, имеющие максимальную численность железоокисляющих и марганецокисляющих (Fe-Ox и Mn-Ox бактерий, являются благоприятной средой для микробного окисления восстановленных форм Fe (II) и Mn (II).

3. Высокие содержания в верхних интервалах торфяника халькофильных элементов $(\mathrm{Pb}, \mathrm{Zn}, \mathrm{Cd}, \mathrm{Hg}$, As) связаны с антропогенной нагрузкой на экосистему болота в XX-XXI вв. Высокие содержания $\mathrm{Cu}$ и $\mathrm{Mn}$ в верхнем интервале торфяника связаны с их биофильным характером накопления. Рост содержаний Сa, $\mathrm{Mg}$ и $\mathrm{Sr}$ по разрезу торфяной залежи может косвенно указывать на изменение водного режима и обводненности болота на этапах его развития в голоцене. Для литофильных элементов группы алюминия (Al, K, $\mathrm{Na}, \mathrm{Si})$ характерно резкое увеличение содержаний в нижних высокозольных интервалах торфяника. С глубиной в торфяном разрезе начинают доминировать восстановленные формы S (II) и изменяется характер форм нахождения железа - от оксидов Fе в верхних интервалах до самородного Fе и сульфидов в нижних. O незавершенности процессов минералообразования в торфянике свидетельствуют такие факты, как гелеобразное агрегатное состояние минеральных масс, псевдоморфозы, отсутствие четко выраженной структуры кристаллов Fе.

4. Все диагенетические процессы в торфянике идут в бескислородной, восстановительной обстановке и характеризуются ростом значений $\mathrm{pH}$ по глубине разреза. Рост с глубиной концентраций в болотных водах $\mathrm{HCO}_{3}{ }^{-}, \mathrm{NH}_{4}{ }^{+}, \mathrm{NO}_{3}{ }^{-}, \mathrm{PO}_{4}{ }^{3-}$ приводит к их метаморфизации и является отражением деструкции органического вещества торфа в диагенезе. По глубине разреза торфяника в болотных водах отмечается существенный рост содержаний $\mathrm{Cl}^{-}, \mathrm{Ca}^{2+}$ и $\mathrm{Mg}^{2+}$. Значимое снижение $\mathrm{SO}_{4}{ }^{2-}$ отмечено только в воде, пронизывающей минеральные отложения, и связано с процессами аутигенного минералообразования (формирования $\mathrm{FeS}_{2}$ ).

5. Смена окислительно-востановительных условий среды вследствие деструкции органического вещества способствует восстановлению окисленных форм Fe (III), Mn (IV) до подвижных Fe (II), Mn (II) и их дальнейшую миграцию в болотную воду. Образование комплексных соединений с органическим веществом определяет накопление в болотных водах верхних интервалов торфяника $\mathrm{Fe}, \mathrm{Mn}, \mathrm{Zn}$ и $\mathrm{Cu}$. Процессы диагенеза также приводят к выщелачиванию ряда химических элементов (Ca, $\mathrm{Mg}, \mathrm{Sr}, \mathrm{Pb}, \mathrm{Ba}$ ) в болотную воду из твердой фазы торфа. Разрушение алюмосиликатных минералов приводит к накоплению в болотных водах с глубиной $\mathrm{Al}$ и $\mathrm{Si}$. На распределение химических элементов помимо диагенетических преобразований в разрезе торфяника влияет и характер колебаний уровня болотных вод. 
Исследование выполнено при финансовой поддержке РФФИ в рамках научных проектов № 11-05-00655 А, № 19-05-00403 А и № 18-35-00072 мол_а. Работа выполнена по государственному заданию ИГМ СО РАН. Аналитические исследования выполнены в ЦКП многоэлементных и изотопных исследований СО РАН.

\section{ЛИТЕРАТУРА}

Алекин О.А. Основы гидрохимии. Л.: Гидрометеоиздат, 1970, 444 с.

Архипов В.С., Маслов С.Г. Состав и свойства типичных видов торфа центральной части Западной Сибири // Химия растительного сырья, 1998, № 4, с. 9-16.

Архипов В.С., Прейс Ю.И., Бернатонис В.К., Маслов С.Г., Антропова Н.А. Битуминозные торфа Томской области. Томск: STT, 2008, 240 с.

Безрукова Е.В., Кривоногов С.К., Вершинин К.Е., Абзаева А.А., Летунова П.П., Орлова Л.А., Крапивина С.М. Изменения природной среды и климата в котловине озера Байкал в позднеледниковье и голоцене // Доклады международного APN-START симпозиума по изучению глобальных изменений в Северо-Восточной Азии (Владивосток, 7-8 октября 2002 г.). Владивосток: Дальнаука, 2005. с. 5-24.

Безрукова Е.В., Кривоногов С.К., Такахара Х., Вершинин К.Е., Мийоши Н., Накамура Т., Абзаева А.А., Морита Й., Кавамуро К., Шиномия Т., Крапивина С.М. Летопись позднечетвертичной и голоценовой истории юго-восточного побережья оз. Байкал по материалам скважины «Дулиха» // Проблемы реконструкций климата и природной среды голоцена и плейстоцена Сибири, вып. 2. Новосибирск: изд-во Ин-та археологии и этнографии СО РАН, 2000, с. 36-47.

Беляев Н.А. Органическое вещество и углеводородные маркеры Белого моря: Автореф. дис. ...к-та геол.-мин. наук. М., 2015, 24 с.

Бобров В.А., Богуш А.А., Леонова Г.А., Краснобаев В.А., Аношин Г.Н. Аномальные проявления концентраций цинка и меди в торфянике верхового болота Южного Прибайкалья // Доклады РАН, 2011, т. 439, № 6, с. 784-788.

Бобров В.А. Будашкина В.В., Мельгунов М.С., Леонова Г.А., Мальцев А.Е. Природные и техногенные радиоизотопы и микроэлементы в разрезе торфяной залежи верхового болота Дулиха (Прибайкалье): ретроспективные оценки атмосферного поступления минерального вещества // Геология и минерально-сырьевые ресурсы Сибири, 2019, № 2 (38), с. 93-102.

Василевич Р.С. Микроэлементный состав мерзлотных бугристых торфяников криолитозоны европейского северо-востока России // Западно-Сибирские торфяники и цикл углерода: прошлое и настоящее. Томск: Издательский дом ТГУ, 2017, с. 131-133.

Веретенникова Е.Э. Содержание и распределение химических элементов в торфах южно-таежной подзоны Западной Сибири // География и природные ресурсы, 2013, № 2, c. 89-95.

Ветров А.А., Семилетов И.П., Дударев О.В., Пересыпкин В.И., Чаркин А.Н. Исследование состава и генезиса органического вещества донных осадков ВосточноСибирского моря // Геохимия, 2008, № 2, с. 183-195.

Волков И.И. Геохимия серы в осадках океана. М.: Наука, 1984, 272 с.

Гавшин В.М., Сухоруков Ф.В., Будашкина В.В., Мельгунов М.С., Бобров В.А. Свидетельства фракционирования химических элементов в атмосфере Западной Сибири по данным исследования верхового торфяника // Геохимия, 2003, № 12, с. 1337-1344. 
Геохимия диагенеза осадков Тихого океана (трансокеанский профиль). М.: Наука, 1980, 288 c.

Гранина Л.3. Ранний диагенез донных осадков озера Байкал. Новосибирск: Академическое изд-во «Гео», 2008, 156 с.

Ефремова Т.Т., Ефремов С.П., Куценогий К.П., Онучин А.А., Переседов В.Ф. Биогеохимия $\mathrm{Fe}, \mathrm{Mn}, \mathrm{Cr}, \mathrm{Ni}, \mathrm{Co}, \mathrm{Ti}, \mathrm{V}$, Mo, Ta, W, U в низинном торфянике на междуречье Оби и Томи // Почвоведение, 2003, № 5, с. 557-567.

Иванов М.В., Каравайко Г.И. Геологическая микробиология // Микробиология, 2004, т. 73, № 5, с. 581-597.

Иметхенов А.Б. Позднекайнозойские отложения побережья озера Байкал. Новосибирск, Наука, 1987, 151 с.

Карпов И.К. Физико-химическое моделирование в геохимии. Новосибирск, Наука, 1981, 246c.

Конторович А.Э. Геохимические методы количественного прогноза нефтегазоносности. М., Недра, 1976, 250 с.

Леонова Г.А., Бобров В.А., Мальцев А.Е. Биогеохимия голоценового разреза торфяника болотного массива Дулиха (Южное Прибайкалье) // Западносибирские торфяники и цикл углерода: прошлое и настоящее. Материалы Пятого международного полевого симпозиума, 2017, с. 152-154.

Леонова Г.А, Мальцев А.Е., Меленевский В.Н., Мирошниченко Л.В., Кондратьева Л.М., Бобров В.А. Геохимия диагенеза органогенных осадков на примере малых озер юга западной Сибири и Прибайкалья // Геохимия, 2018, № 4, с. 363-382.

Леонова Г.А., Копотева Т.А., Меленевский В.Н., Мальцев А.Е., Климин М.А., Бобров В.А. Методический подход к выявлению источников и генезиса захороненного органического вещества в голоценовых разрезах озерных сапропелей (юг Западной Сибири и Восточное Прибайкалье) // Геология и геофизика, 2019, т. 60 (11), с. 1602-1626.

Лукашев К.И., Ковалев В.А., Жуховицкая А.Л., Хомич А.А., Генералова В.А. Геохимия озерно-болотного литогенеза. Минск: Наука и техника, 1971, 284 с.

Ляхова И.Г., Косович И. Г. Болота Прибайкалья и их природоохранное значение / Уникальные объекты живой природы бассейна Байкала. Новосибирск: Наука, 1990, 224 с.

Мальцев А.Е., Леонова Г.А., Бобров В.А., Шавекин А.С., Мирошниченко Л.В. Геохимические индикаторы раннего диагенеза на примере верхового болота Дулиха (Прибайкалье) // Литология осадочных комплексов Евразии и шельфовых областей. Материалы IX Всероссийского литологического совещания (с международным участием), Казань, Изд-во Казанского университета, 2019, с. 279-280.

Мац В.Д., Уфимцев Г.Ф., Мандельбаум М.М., Алакшин А.М., Поспеев А.В., Шимараев М.Н., Хлыстов О.М. Кайнозой Байкальской рифтовой впадины: строение и геологическая история. Новосибирск, Изд-во СО РАН, филиал «Гео», 2001, 252 с.

Меленевский В.Н., Леонова Г.А., Конышев А.С. Результаты исследования органического вещества современных осадков озера Белое (Западная Сибирь) по данным пиролитических методов // Геология и геофизика, 2011, т. 52(6), с. 751-762.

Массовая концентрация гидрокарбонатов и величина щелочности поверхностных вод суши и очищенных сточных вод. Методика выполнения измерений титриметрическим методом // РД 52.24.493-2006т. Ростов-на-Дону, 2006, 37 с. 
Методика выполнения измерений массовой концентрации хлоридов в пробах природных и очищенных сточных вод аргентометрическим методом // ПНД Ф 14.1:2.9697. Ростов-на-Дону, 2004, 19 с.

Методика выполнения измерений массовой концентрации сульфат-ионов в пробах природных и сточных вод турбидиметрическим методом // ПНД Ф 14.1:2.159-2000. М. 2005, 11 c.

Намсараев Б.Б., Земская Т.И. Микробиологические процессы круговорота углерода в донных осадках озера Байкал. Новосибирск: Изд-во СО РАН филиал «Гео», 2000, 154 с.

Намсараев Б.Б., Хахинов В.В., Турунхаев А.В. Болотные экосистемы перешейка полуострова Святой Нос // География и природные ресурсы, 2009, №4, с. 66-71.

Определение форм серы. Межгосударственный стандарт топливо твердое минеральное. ГОСТ 30404-2013, Госстандарт России, 01.01.2015.

Перельман А.И. Геохимия природных вод. М.: Наука, 1982, 154 с.

Потехин В.М., Сыроежко А.М., Пекаревский Б.В. Теоретические основы процессов переработки природных энергоносителей. Часть I: Учебное пособие. СПб.: СПбГТИ (ТУ), 2010, 156 с.

Рождествина В.И., Сорокин А.П. Первые находки самородных палладия, платины, золота и серебра в бурых углях Ерковецкого месторождения (Верхнее Приамурье) // Тихоокеанская геология, 2010, № 29 (6), с. 26-38.

Руководство по методам гидробиологического анализа поверхностных вод и донных отложений. Л.,Гидрометеоиздат, 1983, 239 с.

Савельева А.В., Юдина Н.В., Инишева Л.И. Состав гуминовых кислот торфов разной степени гумификации // Химия твердого топлива, 2010, № 5, с. 21-25.

Савичев О.Г. Геохимические показатели болотных вод в таежной зоне Западной Сибири // Известия РАН. Серия географическая, 2015, №4, с. 47-57.

Савичев О.Г., Шмаков А.В. Вертикальная зональность и внутригодовые изменения химического состава вод Тимирязевского болота (Томск, Западная Сибирь) // Известия Томского политехнического университета, 2012, № 320 (1), с. 156-172.

Савичев О.Г., Наливайко Н.Г., Рудмин М.А., Мазуров А.К. Микробиологические условия распределения химических элементов по глубине торфяной залежи в экосистемах восточной части Васюганского болота (Западная Сибирь) // Известия Томского политехнического университета, 2019, № 330 (9), с. 184-194.

Сергеева М.А., Инишева Л.И. Биохимические процессы в олиготрофных торфяных залежах Васюганского болота // Вестник ТГПУ, 2008, № 4 (78), с. 57-63.

Тиссо Б., Вельте Д. Образование и распространение нефти. М.: Мир., 1981, 501 с.

Унифицированные методы анализа силикатных горных пород. ГОСТ 23581.13-79, Госстандарт России, 01.01.1979.

Фадеева В.П., Тихова В.Д., Никуличева О.Н. Элементный анализ органических соединений с использованием автоматических CHNS-анализаторов // Журнал аналитической химии, 2008, т. 63 (11), с. 1197-1210.

Ходжер Т.В. Исследование состава атмосферных выпадений и их воздействия на экосистемы Байкальской природной территории: автореф. дис. ... д. геогр. н. М., 2005, 44 C. 
Чудненко К.В. Термодинамическое моделирование в геохимии: теория, алгоритмы, программное обеспечение, приложения. Новосибирск, Академическое издательство «Гео», 2010, 287 c.

Шварцев С.Л., Серебренникова О.В., Здвижков М.А., Савичев О.Г., Наймушина O.C. Геохимия болотных вод нижней части бассейна Томи (юг Томской области) // Геохимия, 2012 № 4, с. 403-417.

Юдович Я.Э., Кетрис М.П. Геохимические индикаторы литогенеза (литологическая геохимия). Сыктывкар: Геопринт, 2011,742 с.

Юдович Я.Э., Кетрис М.П. Геохимия марганца. Изд-во: Геопринт, Сыктывкар, 2014, 540 c.

Fischer W.R., Schwertmann U. The formation of hematite from amorphous iron (III) hydroxide // Clays and Clay Mineralogy, 1975, № 23, p. 33-37.

Gentsch N., Mikutta R., Alves R.J.E., Barta J., Čapek P., Gittel A., Hugelius G., Kuhry P., Lashchinskiy P., Palmtag J, Richter A., Šantrủčková A, Schnecker J., Shibistova O, Urich T., Wild B., Guggenberger G. Storage and transformation of organic matter fractions in cryoturbated permafrost soils across the Siberian Arctic // Biogeosciences, 2015, v. 12, p. 4525-4542.

Goldstein G.I., Newbury D.E., Echlin P., Joy D.C., Fiori C., Lifshin E. Scanning electron microscopy and x-ray microanalysis. New York: Plenum Press, 1981, 235 p.

Helmer E.H., Urban N.R., Eisenreich S.J. Aluminum geochemistry in peatland waters // Biogeochemistry, 1990, v. 9, № 3, p. 247-276.

Krivonogov S.K. The problem of interpretation of the sediments of low terraces of the $\mathrm{Ob}$ River (Western Siberia) // Bulletin of the commission on investigation of the Quaternary period. 2009, № 69, p. 106-116.

Krivonogov S.K., Takahara H. Late Pleistocene and Holocene environmental changes recorded in the terrestrial sediments and landforms of Eastern Siberia and Northern Mongolia. In: Kamata, N. (ed.). Proceedings of the International Symposium of the Kanazawa University: 21st Century COE Program. v. 1. Kanazawa University, Kanazawa, 2003, p. 30-36.

Krivonogov S.K., Takahara H., Kuzmin Ya.V., Lyobov A., Orlova A. J., Jull T., Nakamura T., Miyoshi N., Kawamuro K., Bezrukova E.V. Radiocarbon chronology of the Late pleistocene-holocene paleogeographic events in lake Baikal Region (Siberia) // Radiocarbon, 2004, v. 46, № 2, p.745-754.

Labrenz M., Druschel G.K., Thomsen-Ebert T., Gilbert B., Welch S.A., Kemner K.M., Logan G.A., Summons R.E., Stasio G., Bond P.L., Lai B., Kelly S.D., Banfield J.F. Formation of sphalerite (ZnS) deposits in natural biofilms of sulfate-reducing bacteria // Science, 2000, № 290, p. 1744-1747

Leonova G.A., Maltsev A.E., Melenevsky V.N., Krivonogov S.K., Kondratyeva L.M., Bobrov V.A., Suslova M.Y. Diagenetic transformation of organic matter in sapropel sediments of small lakes (southern West Siberia and eastern Transbaikalia) // Quaternary International, 2019, v. 524, p. 40-47.

Mats V.D. The structure and development of the Baikal Rift Depression. BICER, Irkutsk, 1992, 70 p.

Tissot B.P., Welte D.H. Formation and Occurrence: A New Approach to Oil and Gas Exploration. Springer-Varlag, 1978, 538 p.

Trudinger P.A., Lambert I.B., Skyring G.W. Biogenic sulfide ores: a feasibility study // Econ. Geol., 1972, v. 67 (8), p. 1114-1127. 


\section{Подписи к рисункам}

Рис. 1. Стратиграфия кернов бурения торфяника Дулиха: а. керн бурения 2011 г., б. керн бурения 2018 г.. Строение разреза: 1. торф, 2. органо-минеральные отложения (ОМО), 3 подстилающие породы (лёссы); Вещественный состав разреза: 4. почти неразложившийся торф с большим количеством растительных остатков (осок) и сфагнового мха, 5. слаборазложившийся торф (степень разложения менее 20 \%) с большим количеством сфагнового мха, 6. торф, с низким содержанием сфагнового мха и преобладанием осок, 7. разложившийся сфагновый торф, 8. сильноразложившийся сфагновый торф (степень разложения более 50 \%), 9. переходный, высокозольный интервал торфа.

Рис. 2. Распределение по разрезу торфяника Дулиха (керн бурения 2011 года) органического углерода $\left(\mathrm{C}_{\text {орг }}\right)$, органических $\mathrm{H}, \mathrm{N}$ и отношения $\mathrm{C} / \mathrm{N}$, а также валовых значений S, P (легенду см. рис. 2). Данные по C, H, N получены на автоматическом CHNSанализаторе (аналитик к.Х.н. В.Д. Тихова, НИОХ CO PAH), результаты по S, Р получены недеструктивным рентгенофлуоресцентным анализом (аналитик Т.С. Айсуева, ИГХ СО РАН). Легенду см. рис. 2.

Рис. 3. Пиролитическая характеристика изученного разреза торфяника Дулиха. а. ТОС мас. \% общего органического углерода, НІ — водородный индекс (мг УВ/г ТОС), ОI кислородный индекс (мг $\mathrm{O}_{2} / \Gamma$ ТОС); б. Зависимость для исследованных образцов торфа кислородного индекса (ОI) от водородного индекса (НI).

Рис. 4. Пирограммы одного из продуцентов ОВ (сфагновый мох) и образцов торфа из разных интервалов торфяника Дулиха. Отн. интенсивность - скорость (интенсивность) выделения вещества за единицу времени при данной температуре. На графики отмечены зоны низко- $\left(\mathrm{T}_{\text {low }}\right)$, средне- $\left(\mathrm{T}_{\text {mid }}\right)$ и высокотемпературных пиков $\left(\mathrm{T}_{\text {high }}\right)$. Стрелками на пирограммах показаны хорошо выраженные низко- и среднетемпературный пики.

Рис. 5. Дифракционные спектры образцов торфа из разных интервалов торфяника Дулиха.

Рис. 6. Микрофотографии минералов Fе и их энергодисперсионные спектры из разных интервалов керна торфяника Дулиха. а, б. оксиды и гидроксиды Fe (1) на растительных остатках (10 и 40 см соответственно); в. самородное Fe (2) на растительных остатках (400 cм); г. Гидротроилит-? $\mathrm{FeS} \times \mathrm{nH}_{2} \mathrm{O}$ (3) в виде псевдоморфоз по растительным остаткам сфагнума (520 см). Фото электронный сканирующий микроскоп TESCAN MIRA 3 LMU.

Рис. 7. Распределение форм серы (мас. д. \%) по разрезу торфяника Дулиха (керн бурения 2018 года). S (II) — восстановленные соединения серы (сульфидная S, $\mathrm{H}_{2} \mathrm{~S}$ и т.д.), S (IV) сера в составе сульфатов.

Рис. 8. Распределение химических элементов по разрезу торфяника Дулиха (керн бурения 2011 года). Легенду см. рис. 2.

Рис. 9. Изменение основного ионного состава болотных вод с глубиной (\%-экв).

Рис 10. Распределение химических элементов в болотных водах по разрезу торфяника Дулиха (керн бурения 2018 года). Легенду см. рис. 2. 
Таблица 1. Распределение

численности основных

физиологических

групп микроорганизмов по разрезу торфяника Дулиха

\begin{tabular}{|c|c|c|c|c|c|c|c|c|c|}
\hline $\begin{array}{c}\text { Глубина, } \\
\text { см }\end{array}$ & СРБ & Fe-OX & Mn-OX & ФМБ & АМБ & НБ & ДНБ 1 & ДНБ 2 & ОМ \\
\cline { 2 - 10 } & \multicolumn{7}{|c|}{ КОЕ/Г } \\
\hline $0-10$ & 0 & 13600 & 6500 & $248 \times 10^{3}$ & $500 \times 10^{4}$ & $100 \times 10^{3}$ & $9 \times 10^{4}$ & $0.01 \times 10^{3}$ & $170 \times 10^{4}$ \\
\hline $20-30$ & 0 & 550 & 50 & $21 \times 10^{3}$ & $250 \times 10^{4}$ & $10 \times 10^{3}$ & $25 \times 10^{4}$ & $2.5 \times 10^{3}$ & $140 \times 10^{4}$ \\
\hline $100-110$ & 0 & 0 & 170 & $40 \times 10^{3}$ & $17 \times 10^{4}$ & 0 & $60 \times 10^{4}$ & $60 \times 10^{3}$ & $110 \times 10^{4}$ \\
\hline $250-260$ & 0 & 0 & 0 & $1.6 \times 10^{3}$ & $170 \times 10^{4}$ & 0 & $130 \times 10^{4}$ & $25 \times 10^{3}$ & $270 \times 10^{4}$ \\
\hline $350-360$ & 0 & 50 & 0 & $0.7 \times 10^{3}$ & $197 \times 10^{4}$ & 0 & $250 \times 10^{4}$ & $60 \times 10^{3}$ & $180 \times 10^{4}$ \\
\hline $450-460$ & 100 & 0 & 0 & $5.5 \times 10^{3}$ & $277 \times 10^{4}$ & 0 & $260 \times 10^{4}$ & $38 \times 10^{3}$ & $254 \times 10^{4}$ \\
\hline $510-520$ & 500 & 30 & 10 & $2.5 \times 10^{3}$ & $74 \times 10^{4}$ & 0 & $300 \times 10^{4}$ & $20 \times 10^{3}$ & $350 \times 10^{4}$ \\
\hline
\end{tabular}

Примечание. СРБ - сульфатредуцирующие бактерии, Fe-OX — железоокисляющие, Mn-OX — марганецокисляющие микроорганизмы, ФМБ - фосфатмобилизирующие бактерии, АМБ - аммонифицирующие, НБ - нитрифирующие бакерии, ДНБ 1 - денитрификаторы первой стадии $\left(\mathrm{NO}_{3} \rightarrow \mathrm{NO}_{2}\right)$, ДНБ $2-$ денитрификаторы второй стадии $\left(\mathrm{NO}_{3} \rightarrow \mathrm{N}_{2}\right)$, OM - органотрофные микроорганизмы. KOЕ/г колониеобразующие единицы на грамм, кл/г — клеток на грамм. 
Табл. 2. Основные химические показатели (мг/л) болотных вод торфяника Дулиха из разных интервалов керна

\begin{tabular}{|l|l|l|l|l|}
\hline Показатель & $\begin{array}{l}\text { Интервал, } \\
0-10 \text { см }\end{array}$ & $\begin{array}{l}\text { Интервал, } \\
150-175 \text { см }\end{array}$ & $\begin{array}{l}\text { Интервал, } \\
400-425 \text { см }\end{array}$ & $\begin{array}{l}\text { Интервал, } \\
475-500 \text { см }\end{array}$ \\
\hline $\mathrm{Eh}$ & +245 & -80 & -103 & -147 \\
\hline $\mathrm{pH}$ & 3.2 & 3.8 & 4.4 & 4.8 \\
\hline $\mathrm{O}_{2}$ & 4.76 & - & 0.51 & 0.73 \\
\hline $\mathrm{POY}$ & 140 & 195 & 208 & 158 \\
\hline $\mathrm{Alk}$ & 0 & - & 0.09 & 0.13 \\
\hline $\mathrm{HCO}_{3}^{-}$ & 0 & 0.85 & 5.49 & 7.93 \\
\hline $\mathrm{SO}_{4}{ }^{--}$ & 2.9 & 1.8 & 2.4 & 0.5 \\
\hline $\mathrm{Cl}^{-}$ & 1.32 & 2.45 & 5.18 & 7.94 \\
\hline $\mathrm{NO}_{3}^{-}$ & 0.70 & 4.16 & 13.10 & 13.98 \\
\hline $\mathrm{NO}_{2}^{-}$ & 0.065 & 0.055 & 0.046 & 0.048 \\
\hline $\mathrm{PO}_{4}{ }^{3-}$ & 0.142 & 0.365 & 0.532 & 0.652 \\
\hline $\mathrm{Ca}^{2+}$ & 5.1 & 6.7 & 6.9 & 12.6 \\
\hline $\mathrm{Mg}^{2+}$ & 0.95 & 1.29 & 1.37 & 2.51 \\
\hline $\mathrm{Na}^{+}$ & 2.50 & 2.32 & 2.94 & 3.98 \\
\hline $\mathrm{K}^{+}$ & 0.78 & 0.63 & 0.69 & 0.89 \\
\hline $\mathrm{NH}_{4}^{+}$ & 5.10 & 10.81 & 16.52 & 18.92 \\
\hline $\mathrm{M}$ & 19.51 & 29.46 & 40.86 & 55.71 \\
\hline
\end{tabular}

Примечание. РОУ - растворенный органический углерод, $\mathrm{Alk}$ - общая щелочность $\left(\mathrm{HCO}_{3}{ }^{-}+\mathrm{CO}_{3}{ }^{2-}\right)$, мгэкв/л, M — минерализация. Прочерк - нет данных. Eh - дано в мB. 
Таблица 3. Долевое распределение (\%) химических форм элементов в болотных водах по разрезу торфяника Дулиха

\begin{tabular}{|c|c|c|c|c|c|}
\hline \multirow{2}{*}{$\begin{array}{l}\text { Форма } \\
\text { элемента }\end{array}$} & \multicolumn{5}{|c|}{ Болотная вода. интервал (см) } \\
\hline & $0-10$ & $10-50$ & $150-200$ & $400-450$ & $450-500$ \\
\hline \multicolumn{6}{|c|}{$\mathbf{C a}$} \\
\hline $\mathrm{Ca}^{2+}$ & 97.87 & 98.60 & 97.82 & 98.20 & 96.95 \\
\hline $\mathrm{Ca}\left(\mathrm{HCO}_{3}\right)^{+}$ & 0.00 & 0.00 & 1.01 & 1.03 & 1.82 \\
\hline $\mathrm{CaCO}_{3}{ }^{0}$ & 0.40 & 0.41 & 0.59 & 0.33 & 1.09 \\
\hline $\mathrm{CaSO}_{4}{ }^{-}$ & 1.73 & 0.99 & 0.59 & 0.44 & 0.14 \\
\hline \multicolumn{6}{|c|}{ Mg } \\
\hline $\mathrm{Mg}^{2+}$ & 96.45 & 96.74 & 97.53 & 97.56 & 96.52 \\
\hline $\mathrm{Mg}\left(\mathrm{HCO}_{3}\right)^{+}$ & 1.15 & 1.15 & 1.35 & 1.38 & 2.43 \\
\hline $\mathrm{MgCO}_{3}{ }^{0}$ & 0.22 & 0.27 & 0.00 & 0.24 & 0.78 \\
\hline $\mathrm{MgSO}_{4}{ }^{0}$ & 2.17 & 1.85 & 1.12 & 0.82 & 0.27 \\
\hline \multicolumn{6}{|c|}{$\mathrm{Na}$} \\
\hline $\mathrm{Na}^{+}$ & 99.91 & 99.93 & 99.93 & 99.85 & 99.76 \\
\hline $\mathrm{NaHSiO}_{3}{ }^{0}$ & 0.00 & 0.00 & 0.03 & 0.12 & 0.24 \\
\hline \multicolumn{6}{|c|}{$\mathbf{K}$} \\
\hline $\mathrm{K}^{+}$ & 99.92 & 99.93 & 99.96 & 99.97 & 99.99 \\
\hline $\mathrm{KSO}_{4}{ }^{0}$ & 0.08 & 0.07 & 0.04 & 0.03 & 0.01 \\
\hline \multicolumn{6}{|c|}{ C } \\
\hline $\mathrm{HCO}_{3}^{-}$ & 0.00 & 11.45 & 97.73 & 97.14 & 98.12 \\
\hline $\mathrm{CO}_{2}{ }^{0}$ & 28.52 & 23.66 & 1.89 & 2.21 & 1.38 \\
\hline $\mathrm{CO}_{3}{ }^{2-}$ & 0.00 & 0.00 & 0.38 & 0.65 & 0.50 \\
\hline $\mathrm{H}_{2} \mathrm{CO}_{3}{ }^{0}$ & 71.48 & 64.89 & 4.15 & 3.56 & 0.23 \\
\hline \multicolumn{6}{|c|}{$\mathbf{N}$} \\
\hline $\mathrm{NO}_{2}^{-}$ & 0.54 & 1.31 & 1.31 & 0.78 & 0.78 \\
\hline $\mathrm{NO}_{3}^{-}$ & 99.46 & 98.69 & 98.69 & 99.22 & 99.22 \\
\hline \multicolumn{6}{|c|}{$\mathbf{P}$} \\
\hline $\mathrm{HPO}_{4}^{2-}$ & 0.00 & 0.00 & 84.70 & 0.00 & 89.60 \\
\hline $\mathrm{PO}_{4}^{3-}$ & 59.95 & 0.00 & 0.00 & 0.00 & 0.00 \\
\hline $\mathrm{H}_{2} \mathrm{PO}^{4}$ & 40.05 & 100.00 & 15.30 & 100.00 & 10.40 \\
\hline \multicolumn{6}{|c|}{ Al } \\
\hline $\mathrm{Al}^{3+}$ & 27.66 & 32.80 & 32.53 & 33.18 & 32.32 \\
\hline $\mathrm{AlO}_{2}^{-}$ & 72.34 & 67.20 & 67.47 & 66.82 & 67.68 \\
\hline \multicolumn{6}{|c|}{$\mathbf{F e}$} \\
\hline $\mathrm{Fe}^{2+}$ & 59.95 & 87.07 & 95.20 & 88.62 & 93.33 \\
\hline $\mathrm{Fe}(\mathrm{OH})_{3}{ }^{0}$ & 40.05 & 12.93 & 4.80 & 11.38 & 6.67 \\
\hline \multicolumn{6}{|c|}{ Mn } \\
\hline $\mathrm{Mn}^{2+}$ & 98.94 & 99.37 & 99.70 & 99.73 & 99.82 \\
\hline $\mathrm{MnOH}^{+}$ & 0.13 & 0.13 & 0.00 & 0.06 & 0.11 \\
\hline $\mathrm{MnSO}_{4}{ }^{0}$ & 0.93 & 0.50 & 0.30 & 0.21 & 0.07 \\
\hline \multicolumn{6}{|c|}{$\mathrm{Cu}$} \\
\hline $\mathrm{Cu}^{2+}$ & 100.00 & 33.78 & 33.78 & 33.78 & 33.78 \\
\hline $\mathrm{CuHCO}_{3}{ }^{+}$ & 0.00 & 66.22 & 66.22 & 66.22 & 66.22 \\
\hline \multicolumn{6}{|c|}{ Zn } \\
\hline $\mathrm{Zn}^{2+}$ & 58.94 & 34.09 & 34.09 & 34.09 & 34.09 \\
\hline $\mathrm{ZnHCO}_{3}{ }^{+}$ & 41.06 & 65.91 & 65.91 & 65.91 & 65.91 \\
\hline \multicolumn{6}{|c|}{ Sr } \\
\hline $\mathrm{Sr}^{2+}$ & 100.00 & 99.22 & 99.08 & 99.29 & 98.73 \\
\hline $\mathrm{SrHCO}_{3}{ }^{+}$ & 0.00 & 0.78 & 0.92 & 0.71 & 1.27 \\
\hline \multicolumn{6}{|c|}{ Ba } \\
\hline $\mathrm{Ba}^{2+}$ & 99.98 & 99.59 & 99.52 & 99.63 & 99.34 \\
\hline $\mathrm{Ba}\left(\mathrm{HCO}_{3}\right)^{+}$ & 0.02 & 0.41 & 0.48 & 0.37 & 0.66 \\
\hline \multicolumn{6}{|c|}{ As } \\
\hline $\mathrm{AsO}_{4}^{3-}$ & 0.02 & 0.02 & 0.02 & 0.00 & 0.03 \\
\hline $\mathrm{HAsO}_{4}{ }^{2-}$ & 99.98 & 99.98 & 99.98 & 100.00 & 99.97 \\
\hline \multicolumn{6}{|c|}{ Cd } \\
\hline $\mathrm{Cd}^{2+}$ & 100.00 & 100.00 & 99.01 & 98.22 & 97.33 \\
\hline
\end{tabular}




\begin{tabular}{|c|c|c|c|c|c|}
\hline $\mathrm{CdCl}^{+}$ & 0.00 & 0.00 & 0.99 & 1.78 & 2.67 \\
\hline \multicolumn{6}{|c|}{ Hg } \\
\hline $\mathrm{HgO}^{0}$ & 50.85 & 51.95 & 51.94 & 51.67 & 51.77 \\
\hline $\mathrm{Hg}^{2+}$ & 49.15 & 48.05 & 48.06 & 48.33 & 48.23 \\
\hline \multicolumn{6}{|c|}{ Sb } \\
\hline $\mathrm{HSbO}_{2}{ }^{0}$ & 53.89 & 52.89 & 52.94 & 56.70 & 59.07 \\
\hline $\mathrm{Sb}(\mathrm{OH})_{3}{ }^{0}$ & 46.11 & 47.11 & 47.06 & 43.30 & 40.93 \\
\hline \multicolumn{6}{|c|}{ Co } \\
\hline $\mathrm{Co}^{2+}$ & 99.51 & 99.46 & 99.40 & 100.00 & 99.54 \\
\hline $\mathrm{CoOH}^{+}$ & 0.49 & 0.54 & 0.60 & 0.00 & 0.46 \\
\hline \multicolumn{6}{|c|}{ V } \\
\hline $\mathrm{HVO}_{4}{ }^{2-}$ & 38.50 & 36.88 & 42.23 & 65.21 & 51.15 \\
\hline $\mathrm{H}_{2} \mathrm{VO}_{4}^{-}$ & 61.50 & 63.12 & 57.77 & 34.79 & 48.85 \\
\hline \multicolumn{6}{|c|}{ B } \\
\hline $\mathrm{B}(\mathrm{OH})_{3}{ }^{0}$ & 94.62 & 97.62 & 97.08 & 98.02 & 96.26 \\
\hline $\mathrm{BO}_{2}^{-}$ & 5.38 & 2.38 & 2.92 & 1.98 & 3.74 \\
\hline
\end{tabular}


(a)

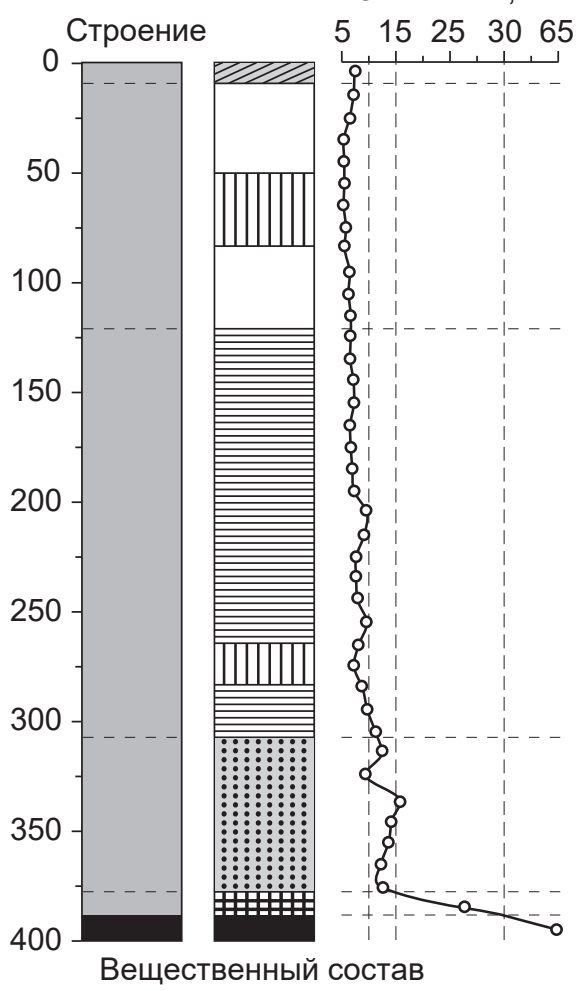

Строение разреза:

1

$2+3$

Вещественный состав разреза: (б)

Зольность, \%

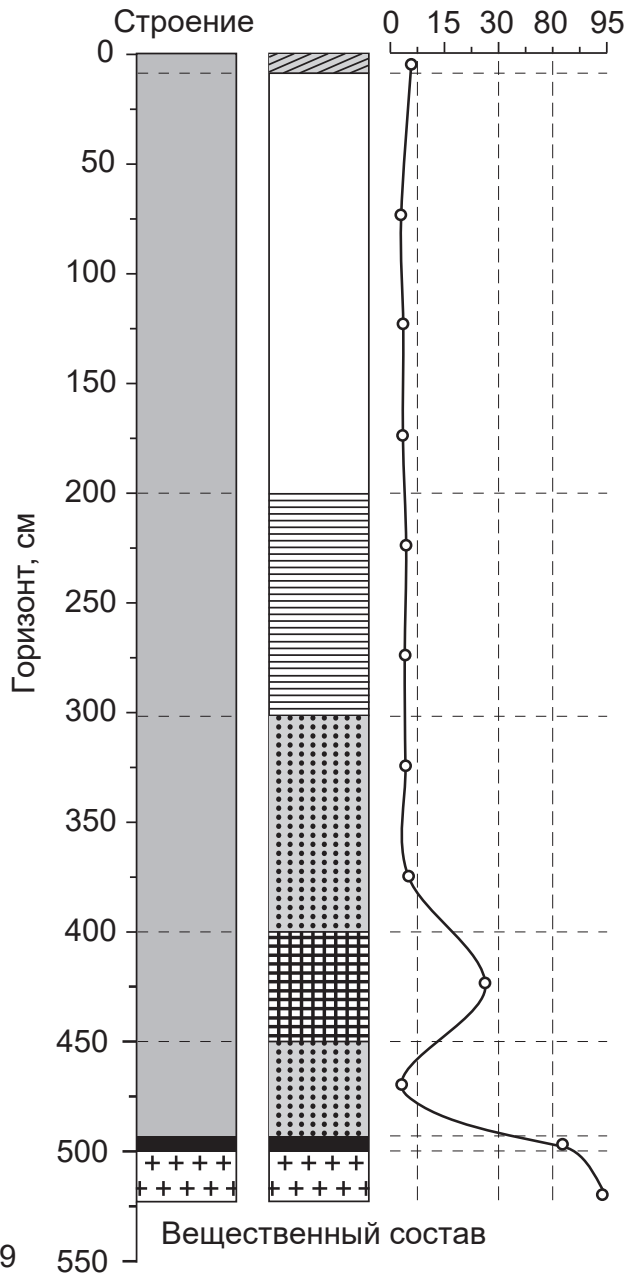




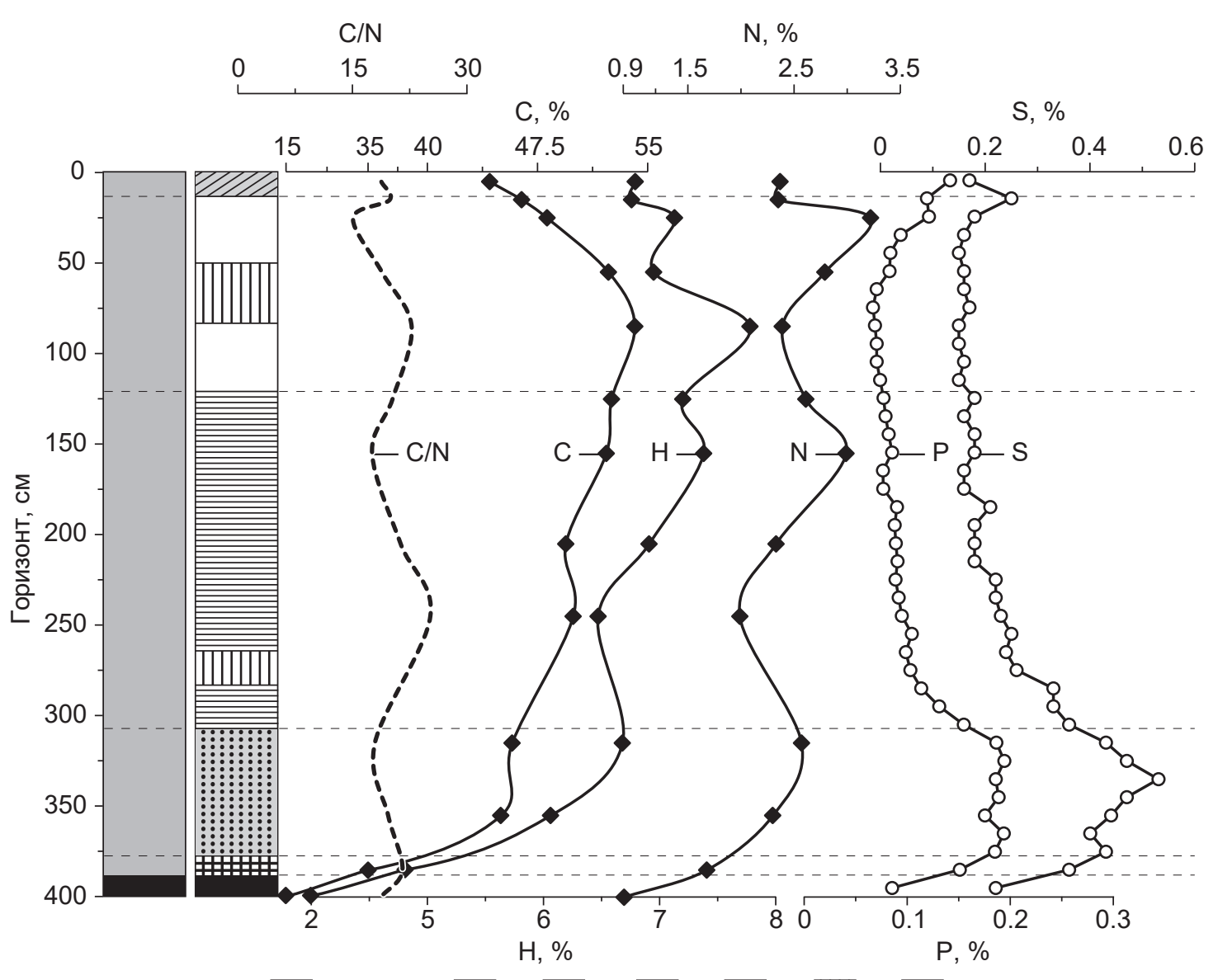

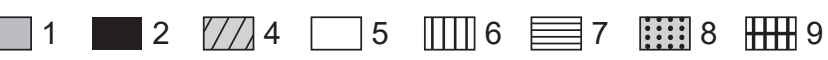


(a)

TOC, HI, OI
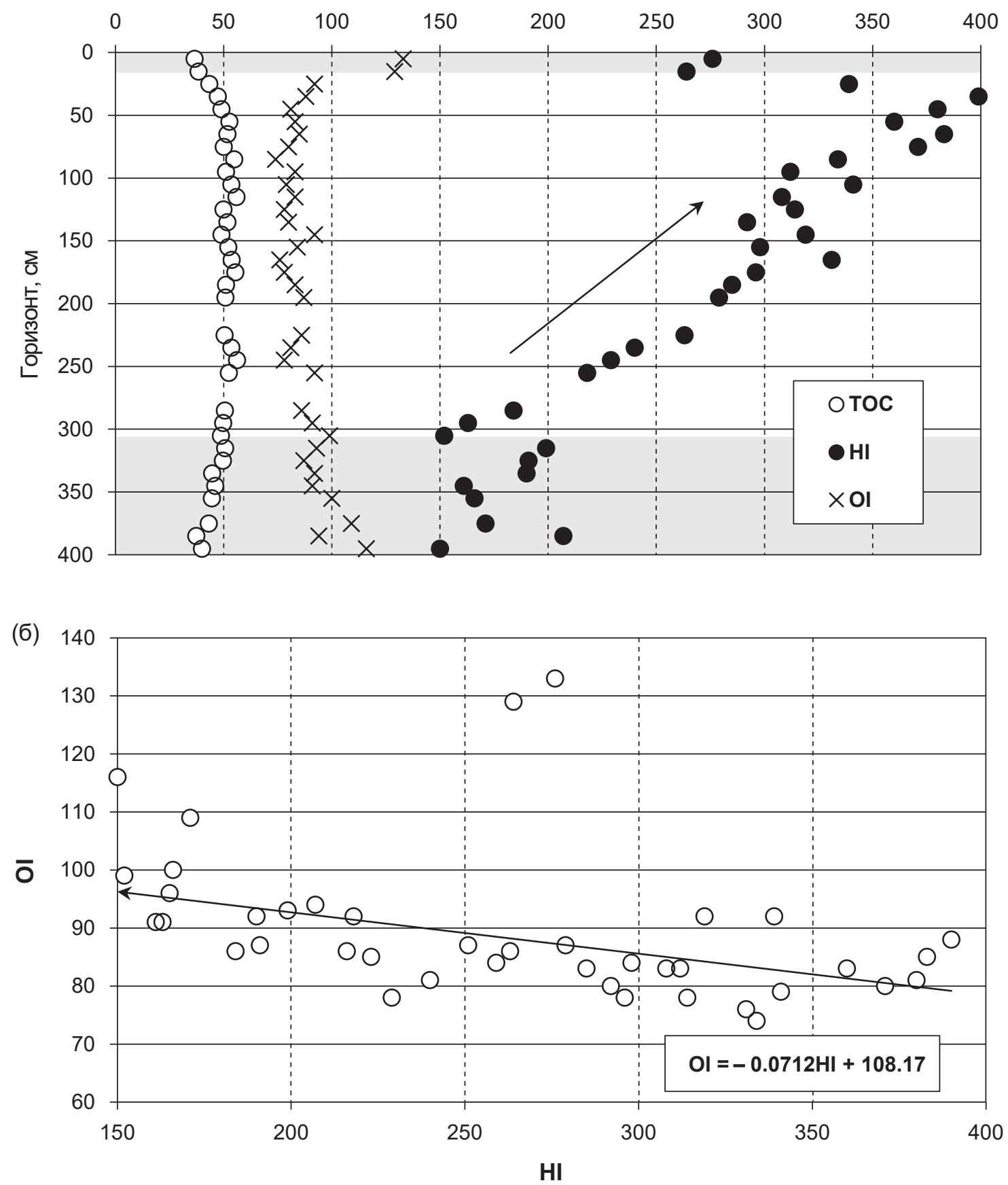


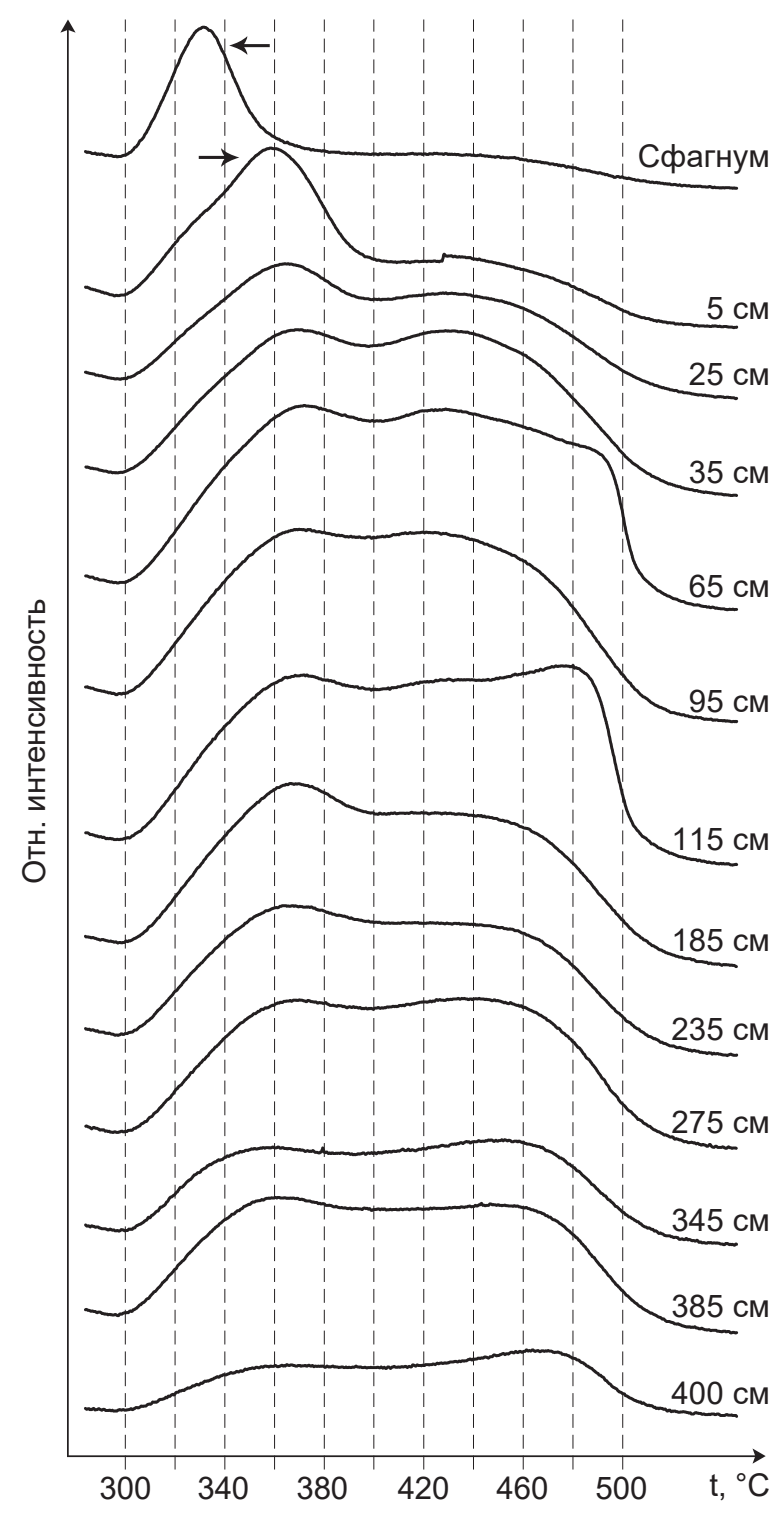




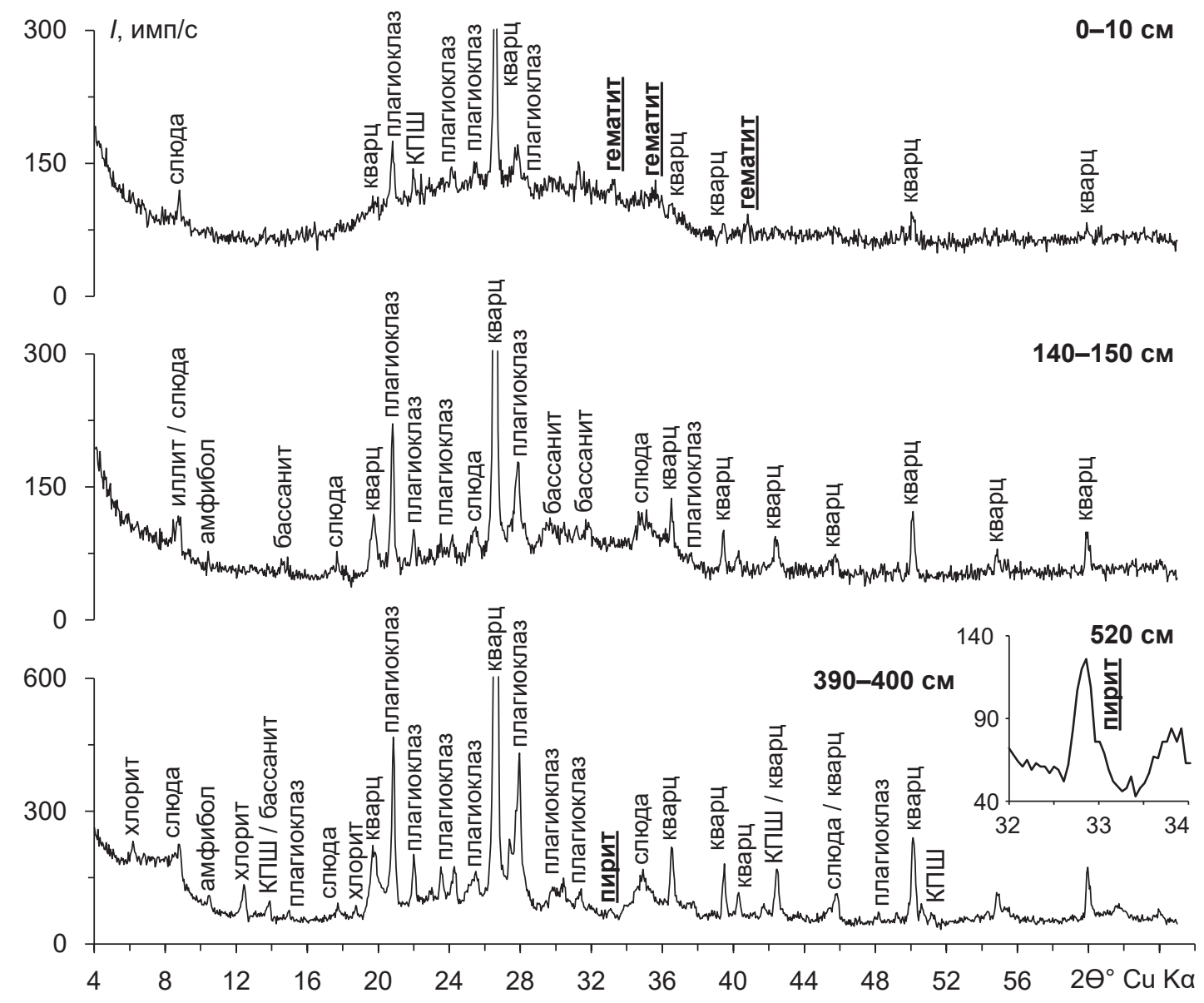



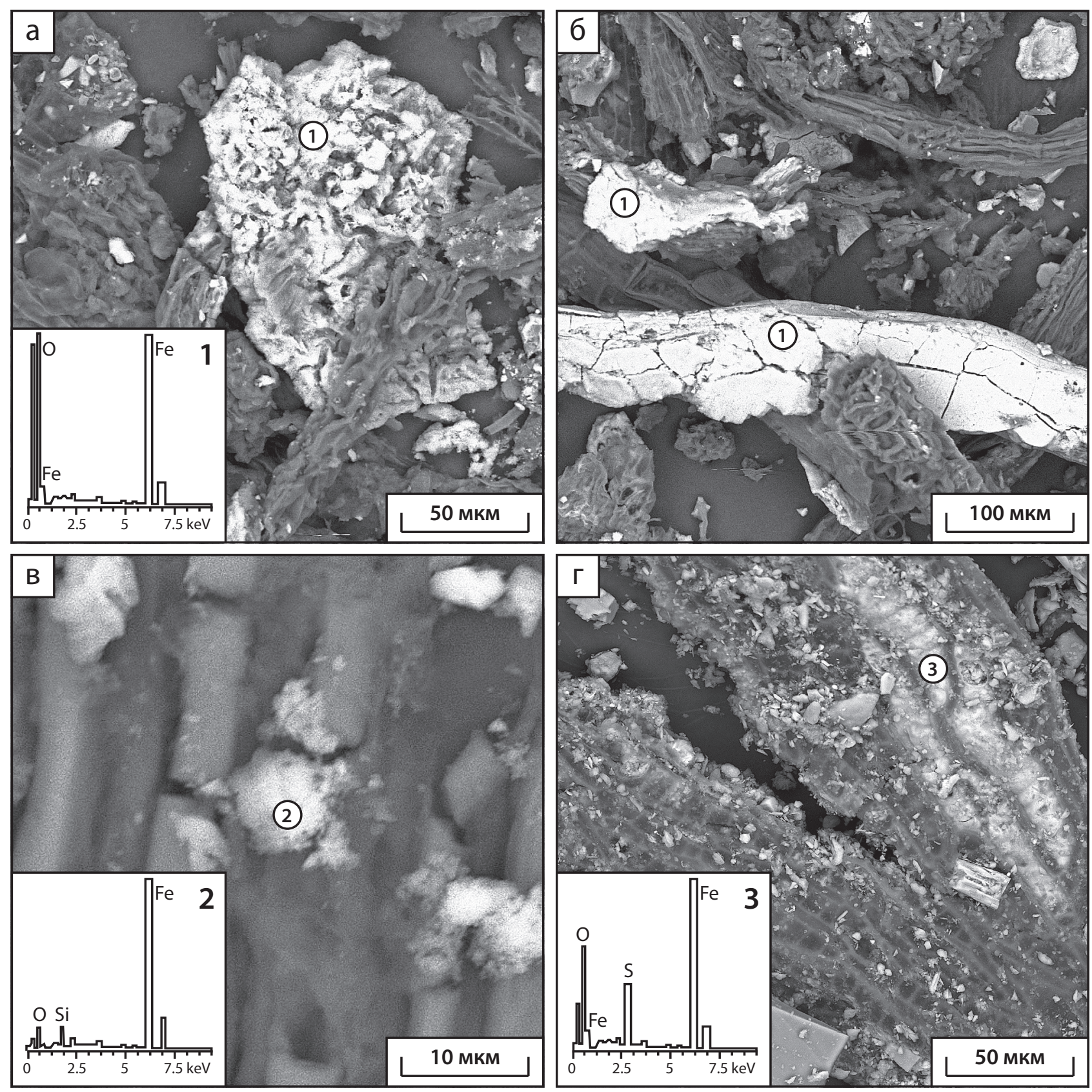


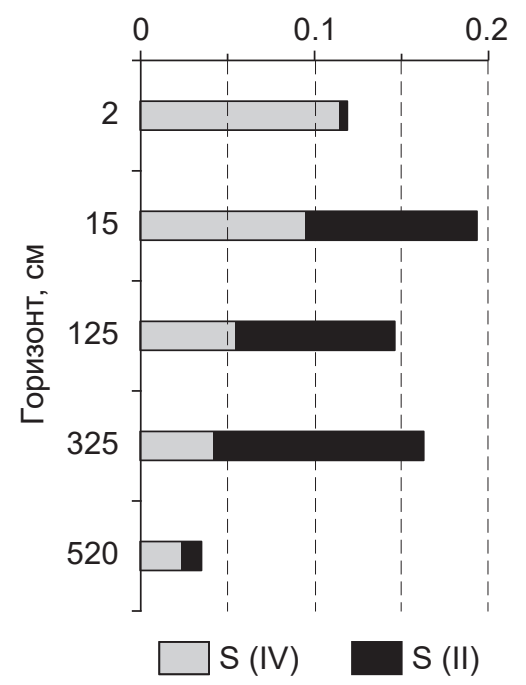




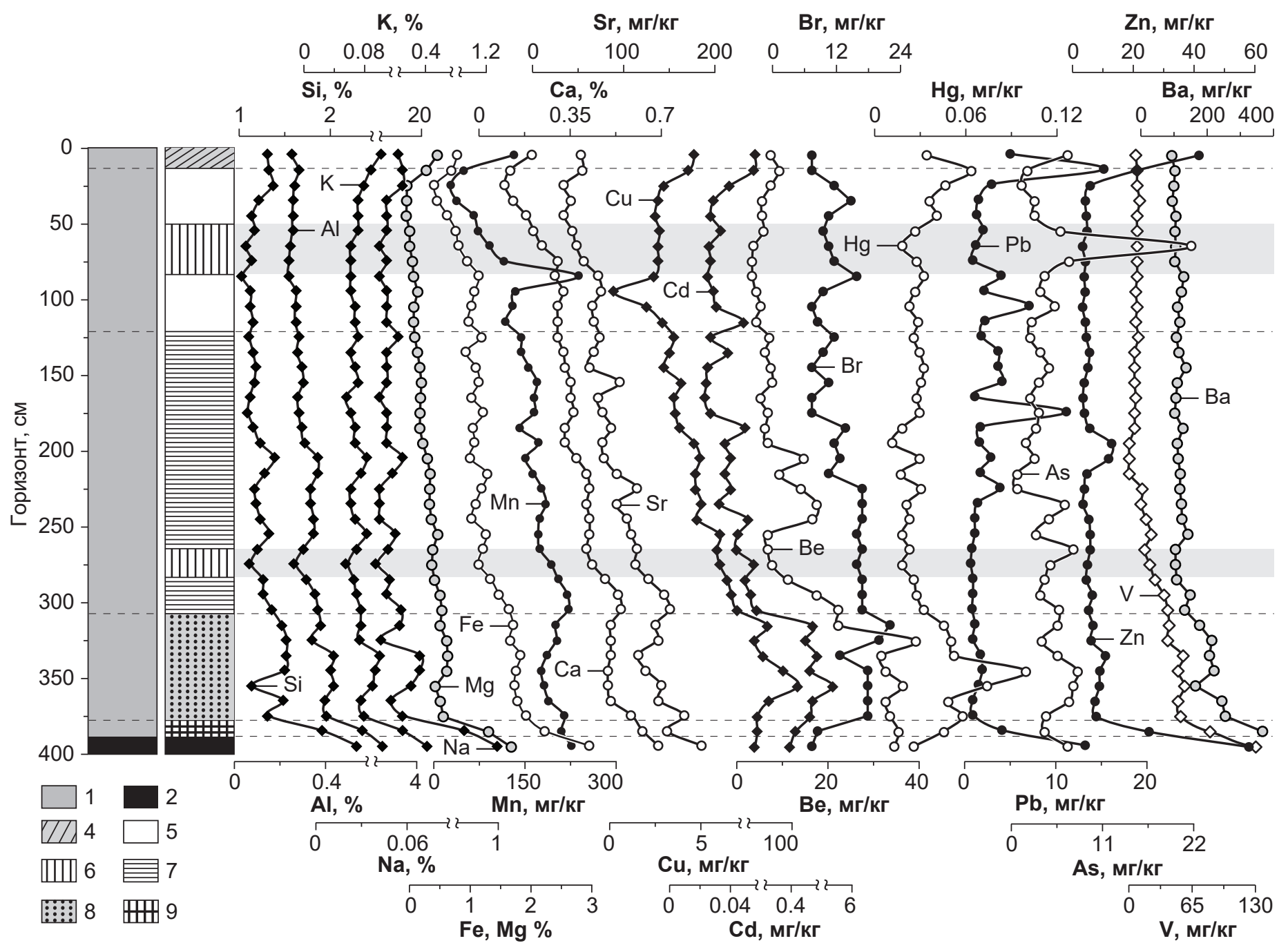




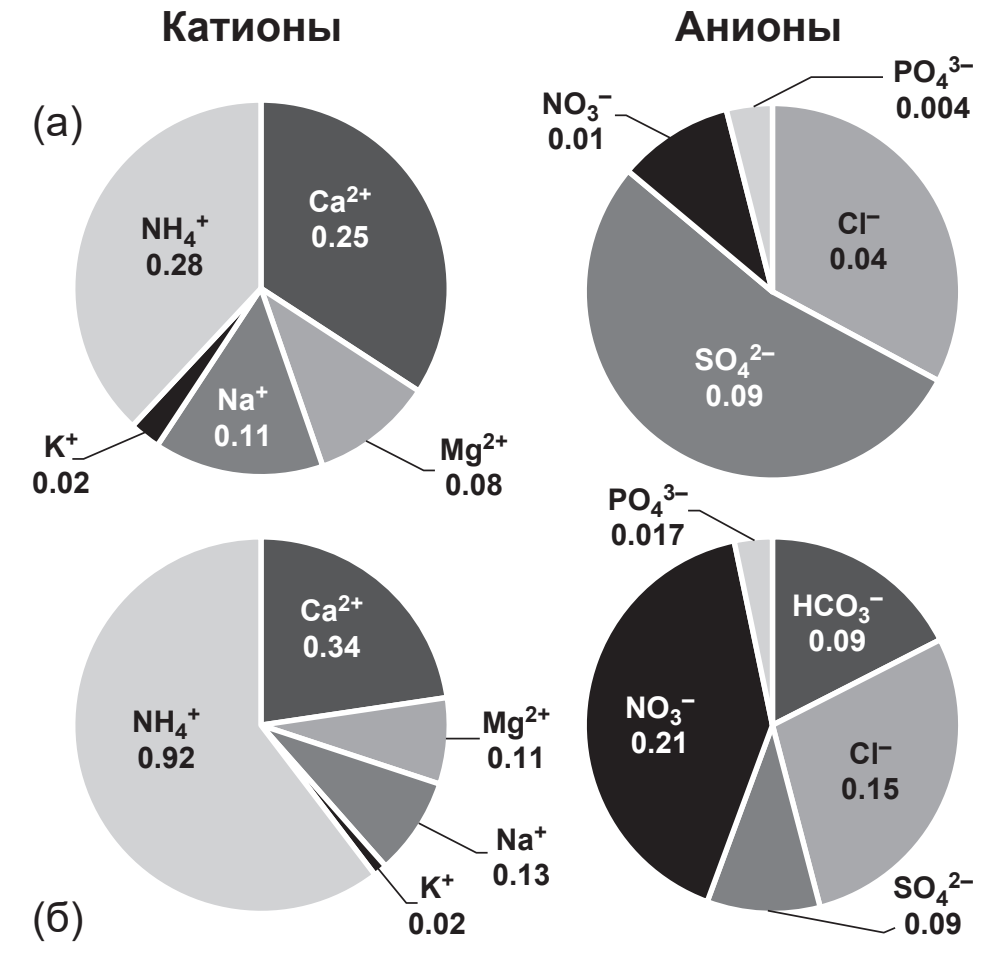




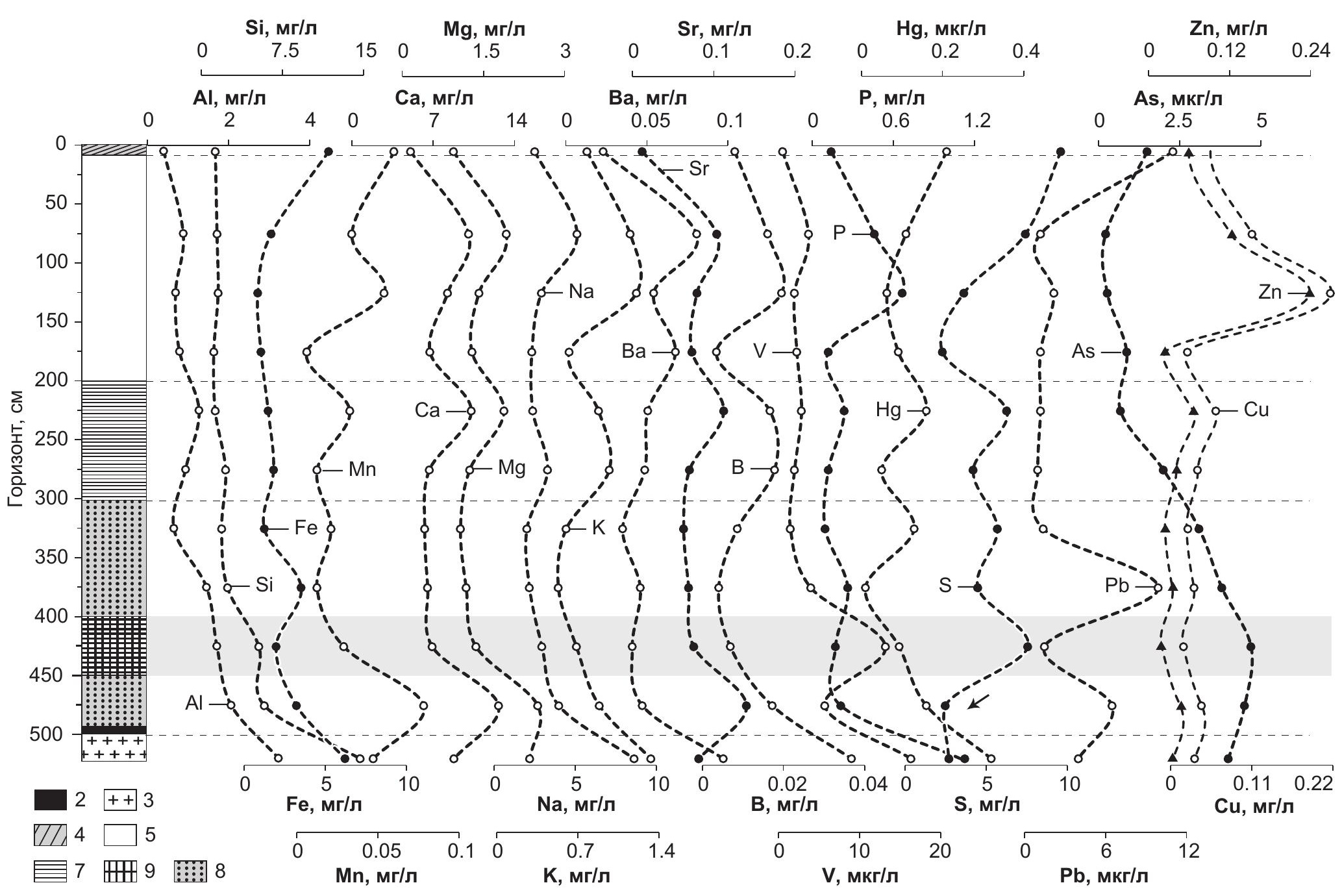

